\title{
Acid-base properties of purine residues and the effect of metal ions: Quantification of rare nucleobase tautomers*
}

\author{
Helmut Sigel \\ Department of Chemistry, Inorganic Chemistry, University of Basel, \\ Spitalstrasse 51, CH-4056 Basel, Switzerland
}

\begin{abstract}
The macro acidity constants valid for aqueous solutions of several adenine, guanine, and hypoxanthine derivatives are summarized. It is shown how the application of the corresponding constants, e.g., for 7,9-dimethyladenine, allows a quantification of the intrinsic acidic properties of the $(\mathrm{N} 1) \mathrm{H}^{0 /+}$ and $(\mathrm{N} 7) \mathrm{H}^{+}$sites via micro acidity constants, and how to use this information for the calculation of the tautomeric ratios regarding the monoprotonated species, that is, $\mathrm{N} 7-\mathrm{N} 1 \cdot \mathrm{H}$ versus $\mathrm{H} \cdot \mathrm{N} 7-\mathrm{N} 1$, meaning that in one isomer $\mathrm{H}^{+}$is at the $\mathrm{N} 1$ site and in the other at N7. It is further shown that different metal ions coordinated to a given site, e.g., N7, lead to a different extent of acidification, e.g., at (N1)H; the effect decreases in the series $\mathrm{Cu}^{2+}>\mathrm{Ni}^{2+}>\mathrm{Pt}^{2+} \sim \mathrm{Pd}^{2+}$. Moreover, the application of micro acidity constants proves that the acidifications are reciprocal and identical. This means, $\mathrm{Pt}^{2+}$ coordinated to $(\mathrm{N} 1)^{-/ 0}$ sites in guanine, hypoxanthine, or adenine residues acidifies the $(\mathrm{N} 7) \mathrm{H}^{+}$unit to the same extent as (N7)-coordinated $\mathrm{Pt}^{2+}$ acidifies the $(\mathrm{N} 1) \mathrm{H}^{0 /+}$ site. In other words, an apparently increased basicity of $\mathrm{N} 7$ upon $\mathrm{Pt}^{2+}$ coordination at $(\mathrm{N} 1)^{-/ 0}$ sites disappears if the micro acidity constants of the appropriate isocharged tautomers of the ligand are properly taken into account. There is also evidence that proton-proton interactions are more pronounced than divalent metal ion-proton interactions, and that these in turn are possibly larger than divalent metal ion-metal ion interactions. The indicated quantifications of the acid-base properties are meaningful for nucleic acids including the formation of certain nucleobase tautomers in low concentrations, which could give rise to mutations.
\end{abstract}

\section{INTRODUCTION}

By early 1953, "the dominant tautomeric structures that occur in the four nucleic bases of DNA" had not yet been definitely described [1]. This deficiency caused base-pairing problems in the formulation of the DNA double-helical structure [2]. However, since then the predominant tautomeric forms and proton binding sites [1,3] of the common nucleobases, which also encompass uracil (being of relevance for RNA [4]), as well as hypoxanthine, which together with the other nucleobases is an important constituent of nucleotides [5-7], have been confirmed by a variety of methods $[1,4,8]$. These nucleobases are depictured in Fig. 1.

*Plenary lecture presented at the $28^{\text {th }}$ International Conference on Solution Chemistry, Debrecen, Hungary, 23-28 August 2003. Other presentations are published in this issue, pp. 1809-1919. 
<smiles>Nc1ccn(P)c(=O)n1</smiles>

$\mathbf{R}=\mathbf{H}$

Cytosine<smiles>CCn1ccc(=O)[nH]c1=O</smiles>

Uracil<smiles>Cc1[nH]c(=O)n(P)c(=O)c1C</smiles>

Thymine<smiles></smiles>

$\mathbf{R}=\mathbf{H}$

Adenine<smiles>O=c1[nH]cnc2c1nc1n2CC1</smiles>

Hypoxanthine<smiles></smiles>

Guanine

Fig. 1 Predominant tautomeric forms of the six most common nucleobases [4,8].

In the upper part of Fig. 1, the three important pyrimidine nucleobases are shown; their acid-base properties are simple, as may be exemplified with the corresponding nucleosides: In these instances, the residues $\mathrm{R}$ in Fig. 1 need to be replaced by a $\beta$-D-ribofuranosyl residue to give cytidine (Cyd) and uridine (Urd), and in the case of thymine by a $2^{\prime}$-deoxy- $\beta$-D-ribofuranosyl residue to give thymidine (dThd). Thus, the cytosine moiety may be protonated at $\mathrm{N} 3$ and the deprotonation of the $(\mathrm{N} 3) \mathrm{H}^{+}$site in cytidine occurs then with $\mathrm{p} K_{\mathrm{H}(\mathrm{Cyd})}^{\mathrm{H}}=4.14 \pm 0.02$ [9]. In contrast, uracil and thymine lose a proton from their (N3)H site and the acidity constants for the corresponding nucleosides uridine (Urd) and thymidine are $\mathrm{p} K_{\mathrm{Urd}}^{\mathrm{H}}=9.18 \pm 0.02[10]$ and $\mathrm{p} K_{\mathrm{dThd}}^{\mathrm{H}}=9.69 \pm 0.03$ [11,12], respectively. The error limits given here and below refer always to three times the standard error of the mean value $(3 \sigma)$ or the sum of the probable systematic errors, whichever is larger. It should also be noted that all equilibrium constants in this article refer to $25{ }^{\circ} \mathrm{C}$ and an ionic strength, $I$, of $0.1 \mathrm{M}\left(\mathrm{NaNO}_{3}\right)$ if nothing else is mentioned. To conclude, the acid-base properties of the $\mathrm{N} 3$ sites of pyrimidines are well characterized and in the physiological $\mathrm{pH}$ range of about $7.5 \mathrm{~N} 3$ of the cytidine residue is accessible for metal ion coordination [13], whereas in the case of the uridine and thymidine residues this is only exceptionally true $[10,11]$ for the biologically important [14] metal ions.

For the purines shown in the lower part of Fig. 1, the situation is much more complicated. Again, replacement, in this case of the hydrogen at N9, by a $\beta$-D-ribofuranosyl residue transfers adenine, hypoxanthine, and guanine into the nucleosides adenosine, inosine, and guanosine, respectively. However, for example, the adenine moiety contains three basic nitrogen atoms $[1,15]$, the most basic site, which accepts the first proton, is N1, next, protonation occurs at N7 and then at N3 [16]. This situation is reflected in the acidity constants summarized in Fig. 2 for threefold protonated adenine (Ade) [16]; of course, the (N9)H site may also be deprotonated with $\mathrm{p} K_{\text {Ade }}^{\mathrm{H}}=9.8$ to give the anionic adeninate [15].

Considering that, for example, in DNA N7 is exposed in the major groove and N3 in the minor one $[4,8]$, one would like to know the basic properties of these two nitrogen sites, yet these properties cannot directly be measured. This is possible only for N1, since here the neutral adenine residue is protonated; the next protonation occurs at N7, but this step is of course affected by the positive charge of the $(\mathrm{N} 1) \mathrm{H}^{+}$site and consequently, the acidity constant $\mathrm{p}_{\mathrm{H}_{2} \text { (Ade) }}^{\mathrm{H}}=-0.4$ (cf. Fig. 2) does not quantify the basicity of $\mathrm{N} 7$ in a neutral adenine residue. Hence, the acid-base properties of N7, and this applies to those of N3 as well, can only be evaluated via micro acidity constants $[17,18]$. Such micro acidity constants will be described below for several purine derivatives, and the effect of metal ions on deprotonation reactions of purine moieties will also be considered (Section 5). 


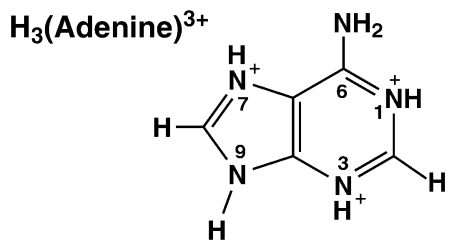

\begin{tabular}{lrc}
\hline Species & $\mathrm{pK}$ & Site \\
\hline $\mathrm{H}_{3}(\text { Ade })^{3+}$ & -4.2 & $(\mathrm{~N} 3) \mathrm{H}^{+}$ \\
$\mathrm{H}_{2}$ (Ade $)^{2+}$ & -0.4 & $(\mathrm{~N} 7) \mathrm{H}^{+}$ \\
$\mathrm{H}$ (Ade $)^{+}$ & 4.2 & $(\mathrm{~N} 1) \mathrm{H}^{+}$ \\
\hline
\end{tabular}

Fig. 2 Acidity constants for threefold protonated adenine; for details see [16].

\section{ACID-BASE PROPERTIES OF 9-METHYLADENINE AND RELATED ADENINE DERIVATIVES}

\subsection{Macro acidity constants of some protonated adenines}

Just like adenine itself (see Fig. 2), 9-methyladenine (9MeA) may also accept three protons. The species $\mathrm{H}_{3}(9 \mathrm{MeA})^{3+}$ is protonated at N3, N7, and N1. The protons are released in this order [16,19], giving rise to the following three equilibria where A represents $9 \mathrm{MeA}$ :

$$
\begin{aligned}
\mathrm{H}_{3}(\mathrm{~A})^{3+} & =\mathrm{H}_{2}(\mathrm{~A})^{2+}+\mathrm{H}^{+} \\
K_{\mathrm{H}_{3}(\mathrm{~A})}^{\mathrm{H}} & =\left[\mathrm{H}_{2}(\mathrm{~A})^{2+}\right]\left[\mathrm{H}^{+}\right] /\left[\mathrm{H}_{3}(\mathrm{~A})^{3+}\right] \\
\mathrm{H}_{2}(\mathrm{~A})^{2+} \rightleftharpoons \mathrm{H}(\mathrm{A})^{+}+\mathrm{H}^{+} & \rightleftharpoons \\
K_{\mathrm{H}_{2}(\mathrm{~A})}^{\mathrm{H}} & =\left[\mathrm{H}(\mathrm{A})^{+}\right]\left[\mathrm{H}^{+}\right] /\left[\mathrm{H}_{2}(\mathrm{~A})^{2+}\right] \\
\mathrm{H}(\mathrm{A})^{+} \rightleftharpoons \mathrm{A}+\mathrm{H}^{+} & \\
K_{\mathrm{H}(\mathrm{A})}^{\mathrm{H}} & =[\mathrm{A}]\left[\mathrm{H}^{+}\right] /\left[\mathrm{H}(\mathrm{A})^{+}\right]
\end{aligned}
$$

Deprotonation according to equilibrium $3 \mathrm{a}$ is expected to occur in the $\mathrm{pH}$ range around 4 (cf. Fig. 2), and, indeed, this acidity constant can be measured by potentiometric $\mathrm{pH}$ titrations [20]. However, the acidity constants due to equilibria 1a and $2 \mathrm{a}$ are accessible only by ${ }^{1} \mathrm{H}$ NMR shift measurements or by UV spectrophotometry [20]. The problem in these cases is that very high concentrations of a strong acid are needed to achieve protonation of the N7 and N3 sites of an adenine derivative [16,20]. Since, for example, aqueous solutions which are 1 or $10 \mathrm{M}_{\text {in }} \mathrm{HClO}_{4}$ do not have a $\mathrm{pH}$ of 0 or -1 , respectively, but show much higher proton activities, their $\mathrm{pH}$ cannot be measured with a glass electrode and a $\mathrm{pH}$ meter.

In those instances where the activity coefficients of perchloric acid or another strong acid differ significantly from 1 , the $\mathrm{H}^{+}$activity may be defined and calculated according to the $H_{0}$ acidity function as originally conceived by Hammett and Deyrup [21]. We applied in our measurements [20] the listing of Paul and Long [22], who tabulated for several strong acids in aqueous solution, including perchloric acid, at $25^{\circ} \mathrm{C}$ the $H_{0}$ values in dependence on the molar concentration of the acid. It should be noted that a $10 \mathrm{M} \mathrm{HClO}_{4}$ solution corresponds roughly to a $H_{0}$ value of -6 . In Fig. 3, a representative example of UV absorption measurements of $9 \mathrm{MeA}$ in the presence of varying amounts of $\mathrm{HClO}_{4}$ is shown. The evaluation of such a series of experiments at various wave lengths is provided in Fig. 4 for the $H_{0} / \mathrm{pH}$ range of -6 to 2 [20]; the legend for Fig. 4 provides further experimental details. These measurements allow an estimation for $K_{\mathrm{H}_{3}(9 \mathrm{MeA})}^{\mathrm{H}}$ (eq. 1) and the determination of $K_{\mathrm{H}_{2}(9 \mathrm{MeA})}^{\mathrm{H}}$ (eq. 2). The final results [20] for $9 \mathrm{MeA}$ regarding eqs. $1 \mathrm{~b}-3 \mathrm{~b}$ are given in entry 1 of Table 1 [23-25].

The $\mathrm{H}_{2}(1,9 \mathrm{DiMeA})^{3+}$ species, where $1,9 \mathrm{DiMeA}^{+}=1$,9-dimethyladenine, carries protons only at the N3 and N7 sites, since N1 is methylated; consequently, in this case only equilibria 1a and 2a apply. Similarly, in $\mathrm{H}_{2}(1 \mathrm{MeAdo})^{3+}$, where $1 \mathrm{MeAdo}^{+}=1$-methyladenosine, $\mathrm{N} 3$ and $\mathrm{N} 7$ are protonated, whereas N1 is methylated; hence, again, equilibria 1a and 2a are the relevant deprotonation reactions. The results [20] for these two adenine derivatives are given in entries 3 and 6 of Table 1, respectively. 


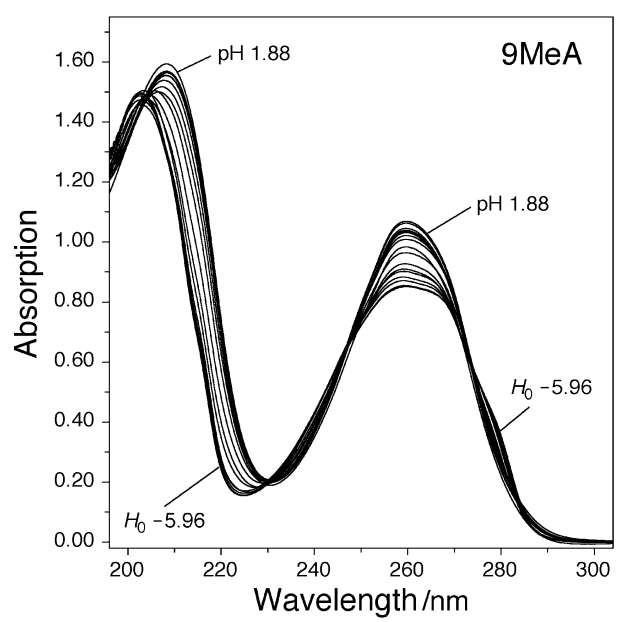

Fig. $3 \mathrm{UV}$ absorption spectra of 9-methyladenine $([9 \mathrm{MeA}]=0.034 \mathrm{mM})$ measured in $2 \mathrm{~cm}$ quartz cells in aqueous solution in dependence on the activity of $\mathrm{H}^{+}$, i.e., the $H_{0} / \mathrm{pH}$ values (see also Fig. 4) were varied from $H_{0}-5.96$, $-5.07,-3.78,-2.47,-1.52,-1.08,-0.86,-0.63,-0.36,-0.10,0.05,0.25,0.46$ to 0.79 and $\mathrm{pH} 1.20,1.54$ to 1.88 $\left(25{ }^{\circ} \mathrm{C} ; \mathrm{I}=0.1 \mathrm{M}, \mathrm{NaClO}_{4}\right.$, except in those solutions where $\left.\left[\mathrm{HClO}_{4}\right]>0.1 \mathrm{M}\right)$. Not all spectral traces of the data points which appear in Fig. 4 are shown. Reproduced by permission of the Royal Society of Chemistry from Fig. S1 of the Supplementary Information of [20].

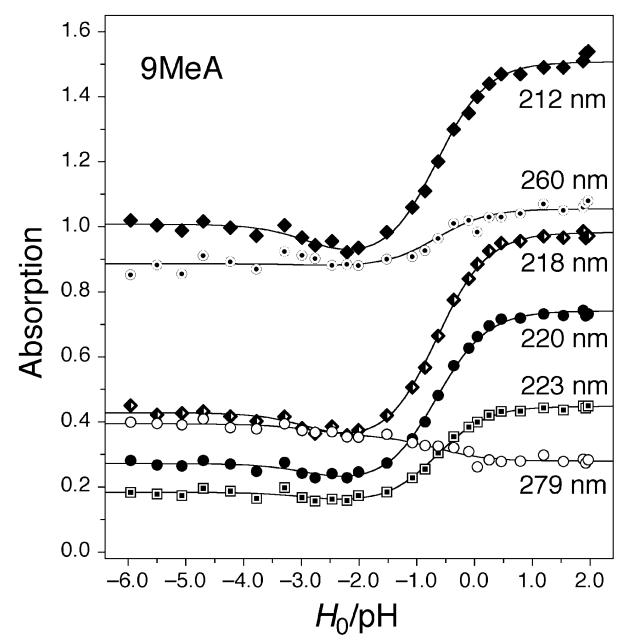

Fig. 4 Evaluation of the dependence of the UV absorption of 9-methyladenine $([9 \mathrm{MeA}]=0.034 \mathrm{mM})$ at 212,218 , $220,223,260$, and $279 \mathrm{~nm}$ on the activity of $\mathrm{H}^{+}$in aqueous solution (see Fig. 3) by plotting the absorption versus $H_{0} / \mathrm{pH}$. The evaluation of this experiment led to the weighted mean $\mathrm{p} K_{\mathrm{H}_{3}(9 \mathrm{MeA})}^{\mathrm{H}}=-2.85 \pm 0.36(3 \sigma)$ and to the following individual acidity constants at the mentioned wavelengths: $212 \mathrm{~nm}, \mathrm{p} K_{\mathrm{H}_{2}(9 \mathrm{MeA})}^{\mathrm{H}}=-(0.59 \pm 0.04) ; 218$ $\mathrm{nm},-(0.66 \pm 0.03) ; 220 \mathrm{~nm},-(0.67 \pm 0.03) ; 223 \mathrm{~nm},-(0.68 \pm 0.04) ; 260 \mathrm{~nm},-(0.41 \pm 0.14) ; 279 \mathrm{~nm},-(0.60 \pm$ $0.19)(1 \sigma)$, which gives the weighted mean $K_{\mathrm{H}_{2}(9 \mathrm{MeA})}^{\mathrm{H}}=-(0.65 \pm 0.09)(3 \sigma)$ for this experiment. The solid curves shown are the computer-calculated best fits at the mentioned wavelengths through the experimental data points obtained at $H_{0}-5.96\left(\left[\mathrm{HClO}_{4}\right]=10.23 \mathrm{M}\right),-5.50(9.61 \mathrm{M}),-5.07(9.03 \mathrm{M}),-4.70(8.51 \mathrm{M}),-4.23(7.86 \mathrm{M}),-3.78$ $(7.22 \mathrm{M}),-3.29(6.59 \mathrm{M}),-2.99(6.20 \mathrm{M}),-2.76(5.88 \mathrm{M}),-2.47(5.42 \mathrm{M}),-2.21(4.97 \mathrm{M}),-2.01(4.58 \mathrm{M}),-1.52$ $(3.61 \mathrm{M}),-1.08(2.65 \mathrm{M}),-0.86(2.17 \mathrm{M}),-0.63(1.69 \mathrm{M}),-0.36(1.20 \mathrm{M}),-0.10(0.84 \mathrm{M}), 0.05(0.60 \mathrm{M}), 0.25$ $(0.36 \mathrm{M}), 0.46(0.24 \mathrm{M}), 0.79(0.12 \mathrm{M})$, and $\mathrm{pH} 1.20,1.54,1.88,1.93$, and 1.97 (from left to right) by using the mentioned average results $\left(25^{\circ} \mathrm{C} ; \mathrm{I}=0.1 \mathrm{M}, \mathrm{NaNO}_{3}\right.$, except in those solutions where $\left.\left[\mathrm{HClO}_{4}\right]>0.1 \mathrm{M}\right)$. Reproduced by permission of the Royal Society of Chemistry from Fig. 2 of [20]. 
Table 1 Negative logarithms of the acidity constants of some protonated adenine derivatives in aqueous solution. ${ }^{\mathrm{a}, \mathrm{b}}$

\begin{tabular}{|c|c|c|c|c|c|}
\hline No. & $\begin{array}{l}\text { Adenine } \\
\text { derivative }\end{array}$ & $\begin{array}{l}\text { Protonated } \\
\text { species }\end{array}$ & $\begin{array}{c}\mathrm{p} K_{\mathrm{a}} \\
(\mathrm{N} 3) \mathrm{H}^{+} \\
(\text {eq. } 1)\end{array}$ & $\begin{array}{c}\mathrm{p} K_{\mathrm{a}} \\
(\mathrm{N} 7) \mathrm{H}^{+} \\
(\text {eq. } 2)\end{array}$ & $\begin{array}{c}\mathrm{p} K_{\mathrm{a}} \\
(\mathrm{N} 1) \mathrm{H}^{+} \\
(\text {eq. } 3)\end{array}$ \\
\hline 1 & 9-Methyladenine & $\mathrm{H}_{3}(9 \mathrm{MeA})^{3+}$ & $-2.83 \pm 0.30^{\mathrm{c}}$ & $-0.64 \pm 0.06^{\mathrm{c}}$ & $4.10 \pm 0.01$ \\
\hline 2 & $\begin{array}{l}\mathrm{N6}^{\prime}, \mathrm{N6}^{\prime}, \mathrm{N} 9- \\
\text { Trimethyladenine }\end{array}$ & $\mathrm{H}_{3}(\operatorname{TriMeA})^{3+}$ & $-2.7^{\mathrm{d}}$ & $-0.77 \pm 0.13^{c}$ & $4.18 \pm 0.04$ \\
\hline 3 & 1,9-Dimethyladenine & $\mathrm{H}_{2}(1,9 \mathrm{DiMeA})^{3+}$ & $-2.72 \pm 0.38^{\mathrm{c}}$ & $-0.79 \pm 0.10^{\mathrm{c}}$ & $(9.1 \pm 0.1)^{\mathrm{e}, \mathrm{f}}$ \\
\hline 4 & 7,9-Dimethyladenine & $\mathrm{H}_{2}(7,9 \mathrm{DiMeA})^{3+}$ & $-2.63 \pm 0.21^{\mathrm{c}}$ & - & $0.50 \pm 0.08^{g}$ \\
\hline 5 & Adenosine & $\mathrm{H}_{3}(\mathrm{Ado})^{3+}$ & $-^{\mathrm{h}}$ & $-1.50 \pm 0.15^{\mathrm{i}}$ & $3.61 \pm 0.03$ \\
\hline 6 & 1-Methyladenosine & $\mathrm{H}_{2}(1 \mathrm{MeAdo})^{3+}$ & $-4.02 \pm 0.28^{c, j}$ & $-1.55 \pm 0.10^{\mathrm{c}}$ & $(8.69 \pm 0.03)^{f}$ \\
\hline 7 & Purine $^{\mathrm{k}}$ & $\mathrm{H}_{3}(\mathrm{Pur})^{3+}$ & $<-6$ & -1.7 & 2.4 \\
\hline
\end{tabular}

aThe above values are abstracted from Table 1 in [20]. The error limits, if nothing else is mentioned, are three times the standard error of the mean value or the sum of the probable systematic errors, whichever is larger.

${ }^{b}$ So-called practical, mixed, or Brønsted constants are listed [23]. If nothing else is mentioned, the constants were determined by potentiometric $\mathrm{pH}$ titrations $\left(25^{\circ} \mathrm{C} ; I=0.1 \mathrm{M}, \mathrm{NaNO}_{3}\right)$. In those instances where the above $\mathrm{p} K_{\mathrm{a}}$ value carries a negative sign, $I$ was considerably higher than $0.1 \mathrm{M}$ (see the legends for Figs. 3 and 4 ).

${ }^{\mathrm{c}}$ Measured by UV spectrophotometry (Figs. 3 and 4 ) at $25^{\circ} \mathrm{C}$ and $I=0.1 \mathrm{M}\left(\mathrm{NaClO}_{4}\right)$ if $\left[\mathrm{HClO}_{4}\right]<0.1 \mathrm{M}$. The values at $\mathrm{pH}>$ 1 were measured with an electrode, lower ones were calculated based on the $H_{0}$ scale (see text in Section 2.1).

${ }^{\mathrm{d}}$ Estimate based on the average of entries 1,3 , and 4 .

'From [24]; error limit estimated.

${ }^{\mathrm{f}}$ This value refers to the deprotonation of the (C6) $\mathrm{NH}_{2}$ group (eq. 4); see text and also Section 4.

${ }^{\mathrm{g}}$ Average from spectrophotometric and ${ }^{1} \mathrm{H}$ NMR shift measurements [20].

$\mathrm{h}$ Ado decomposes under these conditions [16].

${ }^{\mathrm{i}}$ Average of the values given in $[25]$ and $[16,19]$; error limit estimated.

jEstimate; see [20].

kFrom [16,19].

The acidity constants of $\mathrm{H}_{2}(7,9 \mathrm{DiMeA})^{3+}$, where $7,9 \mathrm{DiMeA}^{+}=7,9$-dimethyladenine, refer chargewise to the deprotonation reactions 1 and 2, but it needs to be emphasized that in reaction 2 the (N1) $\mathrm{H}^{+}$site is deprotonated because $\mathrm{N} 7$ is methylated (see Fig. 6, vide infra); reaction 3 does not occur, of course. These two acidity constants for the deprotonation of the $(\mathrm{N} 3) \mathrm{H}^{+}$and $(\mathrm{N} 1) \mathrm{H}^{+}$units are given in entry 4 of Table 1 . The values [20] for threefold protonated $\mathrm{N6}^{\prime}, \mathrm{N} 6^{\prime}, \mathrm{N}$ 9-trimethyladenine, $\mathrm{H}_{3}(\mathrm{TriMeA})^{3+}$ [26], which have much in common with those of $\mathrm{H}_{3}(9 \mathrm{MeA})^{3+}$, and for protonated adenosine are listed in entries 2 and 5, respectively, of Table 1 . Entry 7 contains the values [16,19] for threefold protonated purine [27].

Compounds like $1,9 \mathrm{DiMeA}^{+}$and $1 \mathrm{MeAdo}^{+}$are known to be able to lose a proton from the (C6) $\mathrm{NH}_{2}$ group [24,28]. The resulting zwitterionic species tautomerizes then to the uncharged imino form [24] (see Fig. 12, vide infra in Section 4). For $1 \mathrm{MeAdo}^{+}$the deprotonation reaction 4a holds:

$$
\begin{aligned}
1 \mathrm{MeAdo}^{+} & =(1 \mathrm{MeAdo}-\mathrm{H})+\mathrm{H}^{+} \\
K_{1 \mathrm{MeAdo}}^{\mathrm{H}} & =[(1 \mathrm{MeAdo}-\mathrm{H})]\left[\mathrm{H}^{+}\right] /\left[1 \mathrm{MeAdo}^{+}\right]
\end{aligned}
$$

The corresponding acidity constant (eq. $4 \mathrm{~b}$ ) is listed in entry 6 of Table 1 (column 6 ). This result will be discussed further in Section 4.

In viewing the results of Table 1 , it is interesting to see that $\mathrm{p}_{\mathrm{H}_{2} \text { (Ado) }}^{\mathrm{H}}=-1.50 \pm 0.15$ (Table 1, entry 5$)$ and $\mathrm{p} K_{\mathrm{H}}^{\mathrm{H}}(1 \mathrm{MeAdo})=-1.55 \pm 0.10$ (entry 6 ) are identical; indeed, in both instances the proton is released from the $(\mathrm{N} 7) \mathrm{H}^{+}$site in species which have overall the same charge, but in one instance the hydrogen at $(\mathrm{N} 1) \mathrm{H}^{+}$is replaced by a methyl group. This exchange without a significant alteration of the acid-base properties at another nearby site is possible because of the close similarity of the electro- 
negativity of $\mathrm{H}$ and $\mathrm{CH}_{3}$. This fact is also meaningful regarding the evaluation of micro acidity constants as described in Sections 2.2 and 3.

Considering the above, it is not astonishing that deprotonation of $(\mathrm{N} 3) \mathrm{H}^{+}$in the equally charged $\mathrm{H}_{3}(9 \mathrm{MeA})^{3+}, \mathrm{H}_{2}(1,9 \text { DiMeA })^{3+}$, and $\mathrm{H}_{2}(7,9 \mathrm{DiMeA})^{3+}$ species occurs within the error limits with the same $\mathrm{p} K_{\mathrm{a}}$ (Table 1 , column 4 of entries 1,3 , and 4 ). Replacement of a methyl by a ribose residue at N9 leads to an acidification in all instances. This is especially evident if the $\mathrm{p} K_{\mathrm{a}(\mathrm{N} 3) \mathrm{H}}$ and $\mathrm{p} K_{\mathrm{a}(\mathrm{N} 7) \mathrm{H}}$ values are compared for $\mathrm{H}_{2}(1,9 \mathrm{DiMeA})^{3+}$ with $\mathrm{H}_{2}(1 \mathrm{MeAdo})^{3+}$ (entries 3 and 6); i.e., $\Delta \mathrm{p} K_{\mathrm{a}(\mathrm{N} 3) \mathrm{H}}=-(4.02 \pm$ $0.28)-(-2.72 \pm 0.38)=-1.3 \pm 0.5$ and $\Delta \mathrm{p} K_{\mathrm{a}(\mathrm{N} 7) \mathrm{H}}=-(1.55 \pm 0.10)-(-0.79 \pm 0.10)=-0.76 \pm 0.14$. The two acidifications are significant and possibly also of a similar order (note the error limits).

Substitution of a hydrogen by an amino group at C6 in purine to give adenine enhances the basicity of all $\mathrm{N}$ sites (cf. values in Fig. 2 with those in Table 1, entry 7), yet the additional replacement of a hydrogen by a methyl group at C9 to give 9-methyladenine has little effect on the basicity of N1 (cf. entry 1 in Table 1 with Fig. 2). The comparison of the acidity constants of the same two compounds for their $\mathrm{H}_{3}(\mathrm{~A})^{3+}$ and $\mathrm{H}_{2}(\mathrm{~A})^{2+}$ species, $\mathrm{A}=$ Ade or $9 \mathrm{MeA}$, indicates that $\mathrm{N} 9$ methylation reduces the basicity of N7 only slightly (if at all), but enhances that of N3 significantly [20].

\subsection{Intrinsic acid-base properties of 9-methyladenine}

The acidity constants (Table 1) discussed in the preceding section are macroconstants which apply to the overall properties of a compound. Now we attempt to quantify the intrinsic acid-base properties of a given site by applying micro acidity constants $[17,18]$. Figure 5 summarizes the equilibrium scheme for $\mathrm{H}_{2}(9 \mathrm{MeA})^{2+}$ defining the microconstants $(k)$ and giving their interrelation with the macro acidity constants $(K)$ according to the definitions provided in the lower part of Fig. 5 by following known routes [17]. $\mathrm{H}_{2}(9 \mathrm{MeA})^{2+}$ may release one proton from $(\mathrm{N} 7) \mathrm{H}^{+}$and one from $(\mathrm{N} 1) \mathrm{H}^{+}$and therefore we rewrite $\mathrm{H}_{2}(9 \mathrm{MeA})^{2+}$ as ${ }^{+} \mathrm{H} \cdot \mathrm{N} 7(9 \mathrm{MeA}) \mathrm{N} 1 \cdot \mathrm{H}^{+}$or sometimes even shorter as ${ }^{+} \mathrm{H} \cdot \mathrm{N} 7-\mathrm{N} 1 \cdot \mathrm{H}^{+}$; since deprotonation may occur at either site, we define the monoprotonated forms as $\mathrm{N} 7-\mathrm{N} 1 \cdot \mathrm{H}^{+}$and ${ }^{+} \mathrm{H} \cdot \mathrm{N} 7-\mathrm{N} 1$. Figure 5

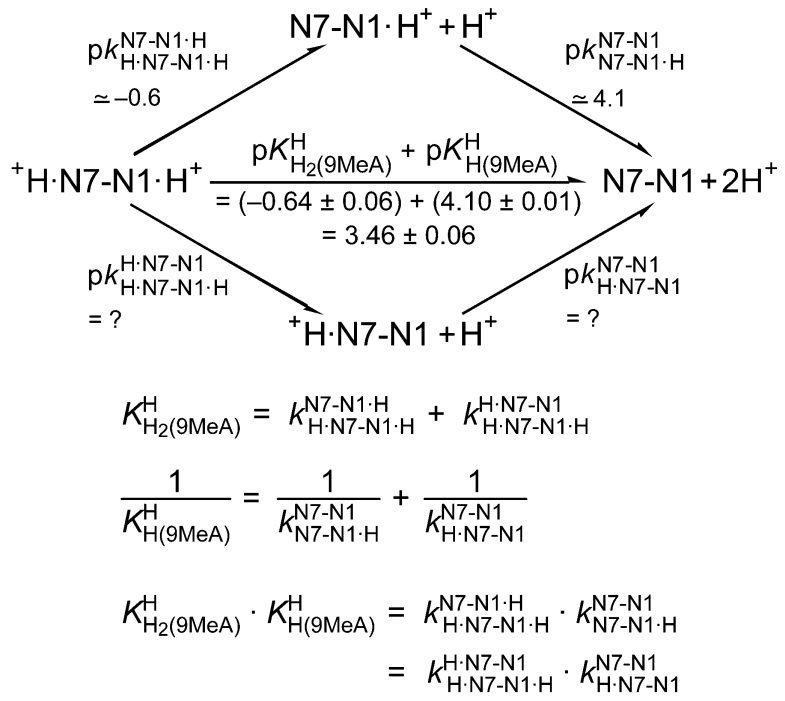

Fig. 5 Equilibrium scheme for 9-methyladenine (9MeA) (Table 1, entry 1) defining the micro acidity constants $(k)$ and showing their interrelation with the measured macroconstants $(K)$ and the connection between $\mathrm{N} 7-\mathrm{N} 1 \cdot \mathrm{H}^{+}$and ${ }^{+} \mathrm{H} \cdot \mathrm{N} 7-\mathrm{N} 1$ and the other species. In N7-N1 $\cdot \mathrm{H}^{+}$and ${ }^{+} \mathrm{H} \cdot \mathrm{N} 7-\mathrm{N} 1$ the proton is bound to $\mathrm{N} 1$ or to N7, respectively; ${ }^{+} \mathrm{H} \cdot \mathrm{N} 7-\mathrm{N} 1 \cdot \mathrm{H}^{+}$is also often written as $\mathrm{H}_{2}(9 \mathrm{MeA})^{2+}$ or sometimes as ${ }^{+} \mathrm{H} \cdot \mathrm{N} 7(9 \mathrm{MeA}) \mathrm{N} 1 \cdot \mathrm{H}^{+}$. The arrows indicate the direction for which the constants are defined. Once one of the micro acidity constants is known, the other microconstants may be calculated with eqs. a-c; see also Fig. 7. 
shows that there are four unknown micro acidity constants, but only three independent equations interrelating them with the macroconstants; this means, one of the microconstants needs to be obtained independently.

Figure 5 indicates that the micro acidity constants in the upper pathway are practically identical with the measured macro acidity constants because the release of the proton from $\left(\mathrm{N}^{2}\right) \mathrm{H}^{+}$is complete before deprotonation at $(\mathrm{N} 1) \mathrm{H}^{+}$begins. How is the situation for the lower pathway? If we recall the observations discussed in Section 2.1 that a hydrogen atom may be replaced by a methyl group without significant alteration of the acid-base properties of nearby sites, $\mathrm{H}(7,9 \mathrm{DiMeA})^{2+}$ with a methyl group at $\mathrm{N} 7$ and a proton at $\mathrm{N} 1$ should mimic well the ${ }^{+} \mathrm{H} \cdot \mathrm{N} 7(9 \mathrm{MeA}) \mathrm{N} 1 \cdot \mathrm{H}^{+}$species. The close similarities of the structures of these two compounds are evident from Fig. 6. Hence, we may conclude that the $(\mathrm{N} 1) \mathrm{H}^{+}$site in $\mathrm{H}(7,9 \mathrm{DiMeA})^{2+}$ represents well the corresponding site in ${ }^{+} \mathrm{H} \cdot \mathrm{N} 7(9 \mathrm{MeA}) \mathrm{N} 1 \cdot \mathrm{H}^{+}$, i.e., $\mathrm{p} k_{\mathrm{H} \cdot \mathrm{N} 7-\mathrm{N} 1 \cdot \mathrm{H}}^{\mathrm{H}}=\mathrm{p} K_{\mathrm{H}(7,9 \mathrm{DiMeA})}^{\mathrm{H}}=0.50 \pm 0.08$. Use of this value in the lower pathway at the left in Fig. 5 allows us now to calculate according to the properties of a cyclic system the microconstant for the release of the proton from $(\mathrm{N} 7) \mathrm{H}^{+}$with $\mathrm{N} 1$ being unprotonated, i.e., $\mathrm{p} k_{\mathrm{H} \cdot \mathrm{N} 7-\mathrm{N} 1}^{\mathrm{N} 1}=2.96 \pm 0.10$, as summarized in Fig. 7.

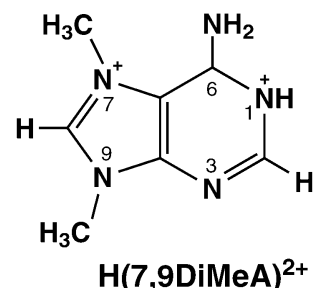<smiles></smiles>

$$
\mathrm{H}_{2}(9 \mathrm{MeA})^{2+}
$$

Fig. 6 The above structures reveal the close similarity between $\mathrm{H}(7,9 \mathrm{MeA})^{2+}$ and $\mathrm{H}_{2}(9 \mathrm{MeA})^{2+}$, which allows the application of $\mathrm{p} K_{\mathrm{H}(7,9 \mathrm{DiMeA})}^{\mathrm{H}}=0.50 \pm 0.08$ (Table 1, entry 4) for $\mathrm{p} \mathrm{H}_{\mathrm{H} \cdot \mathrm{N} 7-\mathrm{N} 1 \cdot \mathrm{H} \cdot \mathrm{H}}^{\mathrm{H}}$ of $\mathrm{H}_{2}(9 \mathrm{MeA})^{2+}$ in the microconstant scheme in Fig. 5 (lower pathway at the left).

However, in developing the upper pathway in Fig. 5 correctly, one cannot simply use the macroconstant $\mathrm{p} K_{\mathrm{H}_{2}}^{\mathrm{H}}(9 \mathrm{MeA})=-0.64 \pm 0.06$ because it is relatively close to the micro constant $\mathrm{p} k_{\mathrm{H} \cdot \mathrm{N} 7-\mathrm{N} 1 \cdot \mathrm{H}}^{\mathrm{H}}=$ $0.50 \pm 0.08$ (see Fig. 7); i.e., the buffer regions of the two deprotonation reactions overlap somewhat, therefore equation (a) given in the lower part of Fig. 5 has to be used for obtaining a value for $\mathrm{p} k_{\mathrm{H} \cdot \mathrm{N} 7-\mathrm{N} 1 \cdot \mathrm{H} / 9 \mathrm{MeA}}^{\mathrm{N}}(=-0.61 \pm 0.06)$ which appears now at the left in the upper pathway of Fig. 7. In fact, this result allows completion of the upper cycle in Fig. 7. Hence, all micro acidity constants relevant for the deprotonation reactions of $\mathrm{H}_{2}(9 \mathrm{MeA})^{2+}$ are now known and completely given in Fig. 7.

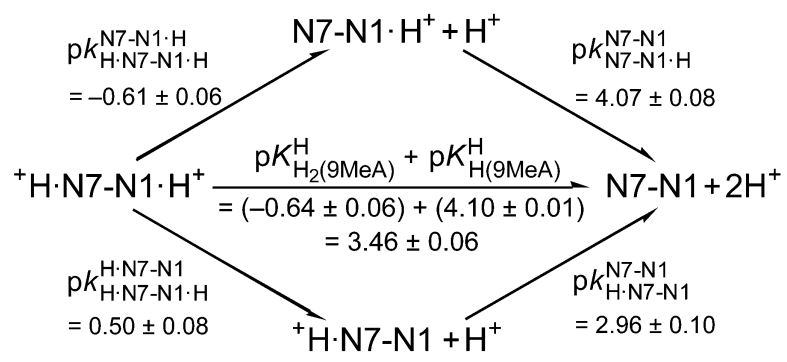

Fig. 7 Microconstant scheme for 9-methyladenine (9MeA); see Fig. 5 and its legend. Application of the value measured for $\mathrm{H}(7,9 \mathrm{DiMeA})^{2+}$ (see Fig. 6), $\mathrm{p} K_{\mathrm{H}(7,9 \mathrm{DiMeA})}^{\mathrm{H}}=0.50 \pm 0.08$ (Table 1, entry 4), to the above micro acidity constant $\mathrm{p} k_{\mathrm{H} \cdot \mathrm{N} 7-\mathrm{N} 1 \cdot \mathrm{H}}^{\mathrm{H}}$ permits calculation of the other microconstants in the scheme by using eqs. a-c of Fig. 5. The error limits of the various constants were calculated according to the error propagation after Gauss; they correspond to three times the standard error (see also Table 1, footnote a). The microconstant scheme is redrawn by permission of the Royal Society of Chemistry from Fig. 5 of [20]. 
To conclude, and this needs to be emphasized: The preceding evaluation has allowed us to quantify the acid-base properties of the adenine residue in $9 \mathrm{MeA}$ : (i) The intrinsic acidity constant for the $(\mathrm{N} 1) \mathrm{H}^{+}$site amounts to $\mathrm{p} k_{\mathrm{N} 7-\mathrm{N} 1 \cdot \mathrm{H}}^{\mathrm{N}}=4.07 \pm 0.08$; a value very close to the macroconstant $\mathrm{p} K_{\mathrm{H}(9 \mathrm{MeA})}^{\mathrm{H}}=$ $4.10 \pm 0.01$. (ii) Much more important, the micro acidity constant for the $(\mathrm{N} 7) \mathrm{H}^{+}$site in the otherwise neutral molecule is $\mathrm{p} k_{\mathrm{H} \cdot \mathrm{N} 7-\mathrm{N} 1}^{\mathrm{N} 1}=2.96 \pm 0.10$, and it is this site which is exposed in the major groove of DNA. (iii) Unfortunately, we are not yet in the position to provide micro acidity constants for the $(\mathrm{N} 3) \mathrm{H}^{+}$site in an otherwise neutral molecule, but based on indirect observations we expect the $\mathrm{p} K_{\mathrm{a}}$ value to be on the order of about 2 .

\section{ACID-BASE PROPERTIES OF 9-METHYLGUANINE AND RELATED NUCLEOBASE DERIVATIVES}

In this section, we shall focus on 9-methylguanine (9MeG) as a representative of hypoxanthine- and guanine-type compounds. $9 \mathrm{MeG}$ can accept protons at N3 and N7 and, in addition, it can release one from the (N1)H site (see Fig. 1). Hence, the following three deprotonation equilibria hold, where G represents $9 \mathrm{MeG}$ (or another related derivative):

$$
\begin{gathered}
\mathrm{H}_{2}(\mathrm{G})^{2+} \rightleftharpoons \mathrm{H}(\mathrm{G})^{+}+\mathrm{H}^{+} \\
K_{\mathrm{H}_{2}(\mathrm{G})}^{\mathrm{H}}=\left[\mathrm{H}(\mathrm{G})^{+}\right]\left[\mathrm{H}^{+}\right] /\left[\mathrm{H}_{2}(\mathrm{G})^{2+}\right] \\
\mathrm{H}(\mathrm{G})^{+} \rightleftharpoons \mathrm{G}+\mathrm{H}^{+} \\
K_{\mathrm{H}(\mathrm{G})}^{\mathrm{H}}=[\mathrm{G}]\left[\mathrm{H}^{+}\right] /\left[\mathrm{H}(\mathrm{G})^{+}\right] \\
\mathrm{G} \rightleftharpoons(\mathrm{G}-\mathrm{H})^{-}+\mathrm{H}^{+} \\
K_{\mathrm{G}}^{\mathrm{H}}=\left[(\mathrm{G}-\mathrm{H})^{-}\right]\left[\mathrm{H}^{+}\right] /[\mathrm{G}]
\end{gathered}
$$

The first proton is released from the $(\mathrm{N} 3) \mathrm{H}^{+}$site with a very low $\mathrm{p} K_{\mathrm{a}}$ value, i.e., $\mathrm{p} K_{\mathrm{H}_{2}(9 \mathrm{MeG})}^{\mathrm{H}} \simeq-1.0$ (cf. footnote $\mathrm{c}$ in Table 2). Reaction 6 is due to the deprotonation of the $(\mathrm{N} 7) \mathrm{H}^{+}$site and the third proton (eq. 7) is released from $(\mathrm{N} 1) \mathrm{H}$ giving rise to the anion $(9 \mathrm{MeG}-\mathrm{H})^{-}$. Most of these macro acidity constants are accessible by potentiometric $\mathrm{pH}$ titrations [20]; the corresponding results for $\mathrm{H}(9 \mathrm{MeG})^{+}$and some related compounds are listed in Table 2 [29-31]. These data speak for themselves and need no further interpretation [20].

However, like in Section 2.2, one may also ask here for the intrinsic acid-base properties, e.g., of the zwitterionic species shown in Fig. 8, which is derived from 9MeG. This type of tautomer is important when a metal ion (e.g., $\mathrm{Pt}^{2+}$ ) coordinates to the $(\mathrm{N} 1)^{-}$site of a guanine or a hypoxanthine derivative, and then, of course, N7 may be protonated despite the metal ion at (N1)- $[30,32]$.

We employ here the same nomenclature already used for Figs. 5 and 7 in Section 2.2. This means, $\mathrm{H}(9 \mathrm{MeG})^{+}$may also be written as ${ }^{+} \mathrm{H} \cdot \mathrm{N} 7(9 \mathrm{MeG}) \mathrm{N} 1 \cdot \mathrm{H}$ and deprotonation may occur at either site giving $\mathrm{N} 7-\mathrm{N} 1 \cdot \mathrm{H}$ or ${ }^{+} \mathrm{H} \cdot \mathrm{N} 7-\mathrm{N}^{-}$. Evidently, the last mentioned tautomer is the one depicted in Fig. 8. To measure directly the release of the proton from the $(\mathrm{N} 7) \mathrm{H}^{+}$site of $9 \mathrm{MeG}$, the $(\mathrm{N} 1)^{-}$site being free, is not possible of course, since (N1) ${ }^{-}$is much more basic than N7. However, by employing the cationic 7,9-dimethylguanine, (7,9DiMeG) ${ }^{+}$, as a mimic for $\mathrm{H}(9 \mathrm{MeG})^{+}$, as is indicated in Fig. 9, allows us to measure the release of the proton from the $(\mathrm{N} 1) \mathrm{H}$ site under conditions where $\mathrm{N} 7$ carries a positive charge (Table 2 , entry 2 ). 
Table 2 Negative logarithms of the acidity constants of some protonated guanine and hypoxanthine derivatives. , $^{\mathrm{b}}$

\begin{tabular}{|c|c|c|c|c|}
\hline No. & Purine & $\begin{array}{l}\text { Protonated } \\
\text { species }\end{array}$ & $\begin{array}{c}\mathrm{p} K_{\mathrm{a}} \\
(\mathrm{N} 7) \mathrm{H}^{+}\end{array}$ & $\begin{array}{c}\mathrm{p} K_{\mathrm{a}} \\
(\mathrm{N} 1) \mathrm{H}^{0}\end{array}$ \\
\hline 1 & 9-Methylguanine ${ }^{c}$ & $\mathrm{H}(9 \mathrm{MeG})^{+}$ & $3.11 \pm 0.06$ & $9.56 \pm 0.02$ \\
\hline 2 & 7,9-Dimethylguanine & 7,9 $\mathrm{DiMeG}^{+}$ & & $7.22 \pm 0.01$ \\
\hline 3 & 9-Methylhypoxanthine & $\mathrm{H}(9 \mathrm{MeHx})^{+}$ & $1.87 \pm 0.01$ & $9.21 \pm 0.01$ \\
\hline 4 & 7,9-Dimethylhypoxanthine & 7,9 $\mathrm{DiMeHx}^{+}$ & & $6.46 \pm 0.01$ \\
\hline 5 & Inosine & $\mathrm{H}(\mathrm{Ino})^{+}$ & $1.06 \pm 0.06^{\mathrm{d}}$ & $8.76 \pm 0.03$ \\
\hline 6 & 7-Methylinosine & $7 \mathrm{MeIno}^{+}$ & & $6.20 \pm 0.01$ \\
\hline
\end{tabular}

${ }^{\mathrm{a}, \mathrm{b}}$ See the corresponding footnotes in Table 1 . The values are abstracted from Table 1 in [20] but they are in part from earlier work [29,30].

${ }^{\mathrm{c}}$ The acidity constant of $\mathrm{H}_{2}(9 \mathrm{MeG})^{2+}$ for the deprotonation of the $(\mathrm{N} 3) \mathrm{H}^{+}$site is estimated as $\mathrm{p} K_{\mathrm{H}_{2}(9 \mathrm{MeG})}^{\mathrm{H}}=-1.0 \pm 0.3$. This constant is the average of the values given in [19] for $\mathrm{H}_{2}$ (guanine) $)^{2+}$; since the acidity constants for the release of the protons from the $(\mathrm{N} 7) \mathrm{H}^{+}$and $\left(\mathrm{N} 1 \mathrm{H}^{+}\right.$sites in $\mathrm{H}(\text { guanine })^{+}$and $\mathrm{H}(9 \mathrm{MeG})^{+}$are relatively similar [30], one may assume that this is also true for the $(\mathrm{N} 3) \mathrm{H}^{+}$site; the given error limit is a generous estimate.

${ }^{\mathrm{d}}$ Measured via ${ }^{1} \mathrm{H}$ NMR shift experiments [31].<smiles></smiles>

Fig. 8 Zwitterionic form of $9 \mathrm{MeG}$, i.e., $(9 \mathrm{MeG})^{ \pm}$, sometimes written as ${ }^{+} \mathrm{H} \cdot \mathrm{N} 7(9 \mathrm{MeG}) \mathrm{N} 1^{-}$.<smiles>Cn1c[n+](C)c2c(=O)[nH]c(N)nc21</smiles>

(7,9DiMeG) ${ }^{+}$<smiles>Cn1c(=O)[nH]c2nc(N)[nH]c21</smiles>

$\mathrm{H}(9 \mathrm{MeG})^{+}$

Fig. 9 The above structures emphasize the close similarity between $(7,9 \mathrm{DiMeG})^{+}$and $\mathrm{H}(9 \mathrm{MeG})^{+}$, which allows the use of $\mathrm{p} K_{7,9 \mathrm{DiMeG}}^{\mathrm{H}}=7.22 \pm 0.01$ (Table 2, entry 2) for $\mathrm{p} k_{\mathrm{H} \cdot \mathrm{N} 7-\mathrm{N} 1 \cdot \mathrm{H}}^{\mathrm{H} \cdot \mathrm{N} 1}$ of $\mathrm{H}(9 \mathrm{MeG})^{+}$in the micro constant scheme in Fig. 10 (lower pathway at the left).

Figure 10 presents the micro constant scheme for the deprotonation reactions of $\mathrm{H}(9 \mathrm{MeG})^{+}$. It reveals that the micro acidity constants in the upper pathway are identical with the measured macro acidity constants because the release of the proton from $(\mathrm{N} 7) \mathrm{H}^{+}$is complete before deprotonation at $(\mathrm{N} 1) \mathrm{H}$ begins. Furthermore, if we use, as indicated above, the acidity constant measured for the release of the proton from the $(\mathrm{N} 1) \mathrm{H}$ site in $(7,9 \mathrm{DiMeG})^{+}$(Table 2, entry 2$)$, then it holds for the deprotonation of $(\mathrm{N} 1) \mathrm{H}$ in ${ }^{+} \mathrm{H} \cdot \mathrm{N} 7(9 \mathrm{MeG}) \mathrm{N} 1 \cdot \mathrm{H}$ that, $\mathrm{p} k_{\mathrm{H} \cdot \mathrm{N} 7-\mathrm{N} 1 \cdot \mathrm{H}}^{\mathrm{H}-\mathrm{N} 1}=\mathrm{p} K_{7,9 \mathrm{DiMeG}}^{\mathrm{H}}=7.22 \pm 0.01$. This value given in the lower pathway at the left in Fig. 10 allows now to calculate according to the properties of a cyclic system the microconstant for the release of the proton from $(\mathrm{N} 7) \mathrm{H}^{+}$with $(\mathrm{N} 1)^{-}$being unprotonated, i.e., $\mathrm{p} k_{\mathrm{H} \cdot \mathrm{N} 7-\mathrm{N} 1}^{\mathrm{N} 1}=5.45 \pm 0.06$ [20]. 


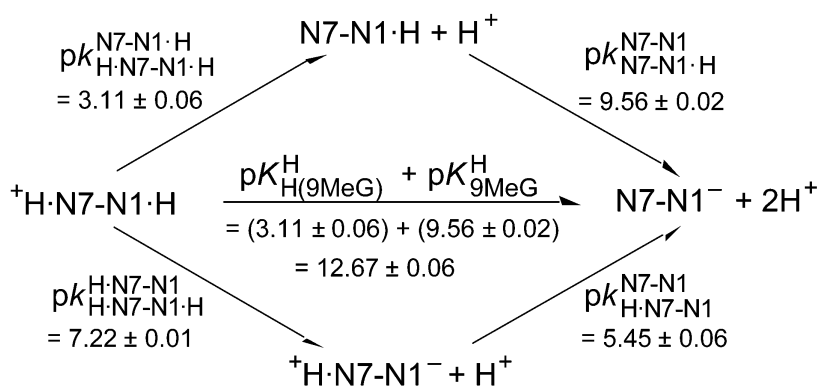

Fig. 10 Microconstant scheme for 9-methylguanine (9MeG) (see also Fig. 5 and its legend). Use of the value measured for (7,9DiMeG) ${ }^{+}$(see Fig. 9), $\mathrm{p} K_{7.9 \mathrm{DiMeG}}^{\mathrm{H}}=7.22 \pm 0.01$ (Table 2, entry 2), for the above micro acidity constant $\mathrm{p} k_{\mathrm{H} \cdot \mathrm{N} 7-\mathrm{N} 1 \cdot \mathrm{H}}^{\mathrm{H}}$ permits calculation of the other microconstants in the scheme (see also legend to Fig. 7). The above scheme is redrawn by permission of the Royal Society of Chemistry from the upper part of Fig. 4 in [20].

The corresponding micro acidity constants may also be calculated [20] for 9-methylhypoxanthine (9MeHx) or inosine (Ino) since the corresponding 7-methyl derivatives have been studied (see Table 2). In fact, these micro acidity constants will be employed in Section 4.

\section{FORMATION DEGREES OF SOME RARE TAUTOMERS OF NUCLEOBASE RESIDUES}

Micro acidity constants as described in Sections 2.2 and 3 for the (N1)H and (N7)H sites of purines are useful and significant quantities. The values derived for $\mathrm{H}_{2}(9 \mathrm{MeA})^{2+}$ and $\mathrm{H}(9 \mathrm{MeG})^{+}$in Sections 2.2 (Fig. 7) and 3 (Fig. 10), respectively, are summarized in part in Table 3, together with the corresponding results of some other related systems. These micro acidity constants also define the intrinsic acidbase properties in aqueous solution of the corresponding individual sites in nucleic acids, at least in a relative sense, and they can also be used to quantify in a proper way the acidifying effects of metal ions [32] (see also Sections 5.2 and 5.3).

Table 3 Micro acidity constants for the (N7)H and (N1)H sites of several purine derivatives, together with the ratios quantifying the formation of the connected tautomers. The measured macro acidity constants, $\mathrm{p} K_{\mathrm{a} /(\mathrm{N} 7) \mathrm{H}}$ and $\mathrm{p} K_{\mathrm{a} /(\mathrm{N} 1) \mathrm{H}}$, are given for comparison. ${ }^{\mathrm{a}}$

\begin{tabular}{llrrrrrrr}
\hline No. & Purine & $\mathrm{p} K_{\mathrm{a} / \mathrm{N}(7) \mathrm{H}}$ & $\mathrm{p} K_{\mathrm{a} /(\mathrm{N} 1) \mathrm{H}}$ & $\mathrm{p} k_{\mathrm{H} \cdot \mathrm{N} 7-\mathrm{N} 1}^{\mathrm{N} 1}$ & $\mathrm{p} k_{\mathrm{N} 7-\mathrm{N} 1 \cdot \mathrm{H}}^{\mathrm{N}-\mathrm{N}}$ & \multicolumn{2}{c}{$\frac{[\mathrm{N} 7-\mathrm{N} 1 \cdot \mathrm{H}]^{\mathrm{c}}}{[\mathrm{H} \cdot \mathrm{N} 7-\mathrm{N} 1]}$} \\
\hline 1 & Ino & $1.06 \pm 0.06$ & $8.76 \pm 0.03$ & $3.62 \pm 0.07$ & $8.76 \pm 0.03$ & 138000 & \pm 24200 \\
2 & $9 \mathrm{MeHx}$ & $1.87 \pm 0.01$ & $9.21 \pm 0.01$ & $4.62 \pm 0.02$ & $9.21 \pm 0.01$ & 38900 & \pm & 2000 \\
3 & $9 \mathrm{MeG}$ & $3.11 \pm 0.06$ & $9.56 \pm 0.02$ & $5.45 \pm 0.06$ & $9.56 \pm 0.02$ & 12900 & \pm & 1900 \\
4 & $\mathrm{H}(9 \mathrm{MeA})^{+}$ & $-0.64 \pm 0.06$ & $4.10 \pm 0.01$ & $2.96 \pm 0.10$ & $4.07 \pm 0.08$ & $12.9 \pm$ & 3.8 \\
\hline
\end{tabular}

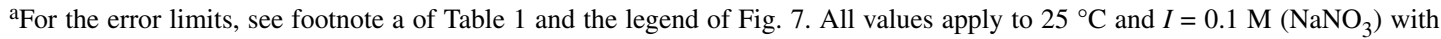
the exception of the value in the third column of entry 4 . The values given in columns 3 and 4 are from Tables 1 (entry 1 ) and 2 (entries 1,3,5); the micro acidity constants are taken from Table 2 in [20] (see also Figs. 7 and 10).

bAbbreviations used: Ino, inosine; 9MeHx, 9-methylhypoxanthine; 9MeG, 9-methylguanine; 9MeA, 9-methyladenine (see also Fig. 1). The protonation degree given with the abbreviations used in column 2 corresponds to that of the tautomers which appear in the ratio of the final column at the right.

${ }^{\mathrm{c}}$ For the calculation procedure, see Fig. 11.

In addition, based on such micro acidity constants (Table 3 ), one may calculate the ratio $R^{*}$ which quantifies the formation degree of the isomeric species having the proton in one tautomer at $\mathrm{N} 1$ and in the other at $\mathrm{N} 7$ (eq. 8): 


$$
R^{*}=\frac{[\mathrm{N} 7-\mathrm{N} 1 \cdot \mathrm{H}]}{[\mathrm{H} \cdot \mathrm{N} 7-\mathrm{N} 1]}=\frac{k_{\mathrm{H} \cdot \mathrm{N} 7-\mathrm{N} 1}^{\mathrm{N} 1}}{k_{\mathrm{N} 7-\mathrm{N} 1 \cdot \mathrm{H}}^{\mathrm{N} 1}}
$$

The procedure for such a calculation is exemplified in Fig. 11 for 9-methylhypoxanthine (9MeHx).

The results for the four systems considered here are listed in the final column of Table 3 . Though $R^{*}$ is somewhat sensitive to relatively small changes in the $\mathrm{p} k$ values involved in the calculations, it is evident that for the guanine and hypoxanthine derivatives the neutral tautomers with the proton at $\mathrm{N} 1$ strongly dominate (see also Fig. 11), with formation degrees close to $100 \%$ allowing only the formation of traces of the zwitterionic species ${ }^{+} \mathrm{H} \cdot \mathrm{N} 7-\mathrm{N}^{-}$. It is interesting to note that substitution of the methyl group at $\mathrm{N} 9$ of the purine residue by a ribose moiety significantly further favors the neutral tautomer (see Table 3, entries 1 and 2). The corresponding observation has been made [20] for guanosine (Guo) where the ratio $\mathrm{N} 7(\mathrm{Guo}) \mathrm{N} 1 \cdot \mathrm{H} /{ }^{+} \mathrm{H} \cdot \mathrm{N} 7-\mathrm{N}^{-}$equals about 80000 to 1 , in other words, it is much higher than the one given for $9 \mathrm{MeG}$ in entry 3 of Table 3 (final column). However, such rare tautomers could well be involved in mutations of the genetic machinery since the ratio given persists in the physiological $\mathrm{pH}$ range (see also the terminating paragraph of this section).

For the adenine derivatives, the situation is somewhat less one-sided; here, both tautomers are formed in appreciable amounts, e.g., monoprotonated 9-methyladenine occurs to about $93 \%$ as the $\mathrm{N} 7-\mathrm{N} 1 \cdot \mathrm{H}^{+}$isomer and to about $7 \%$ in the ${ }^{+} \mathrm{H} \cdot \mathrm{N} 7-\mathrm{N} 1$ form (Table 3 , entry 4 ). The corresponding tautomeric distribution for adenosine [20] is 96 versus $4 \%$. In fact, this means that in $1 \mathrm{ml}$ of a $10^{-3} \mathrm{M}$ Ado solution from the $6 \times 10^{17}$ adenosine molecules present, about $2.4 \times 10^{16}$ molecules carry the proton at N7. However, the relatively high basicity of N7, which is reflected in the mentioned ratios, is of relevance for metal ion binding at this site [33-35], but it is not of relevance for the formation of tautomeric species in the physiological $\mathrm{pH}$ range of about 7.5 since under these conditions the proton is already lost, its $\mathrm{p} K_{\mathrm{a}}$ value being about 4 (Table 3 , entry 4 ).<smiles></smiles>

$(9 \mathrm{MeHx})^{ \pm}$<smiles>C#CCc1nc2c(=O)[nH]cnc2n1C</smiles>

$(9 \mathrm{MeHx})^{0}$

$$
\begin{aligned}
R^{*} & =\frac{\left[(9 \mathrm{MeHx})^{0}\right]}{\left[(9 \mathrm{MeHx})^{ \pm}\right]}=\frac{[\mathrm{N} 7-\mathrm{N} 1 \cdot \mathrm{H}]}{\left[{ }^{+} \mathrm{H} \cdot \mathrm{N} 7-\mathrm{N} 1^{-}\right]} \\
& =\frac{k_{\mathrm{H} \cdot \mathrm{N} 7-\mathrm{N} 1}^{\mathrm{N} 1}}{k_{\mathrm{N} 7-\mathrm{N} 1 \cdot \mathrm{H}}}=\frac{10^{-(4.62 \pm 0.02)}}{10^{-(9.21 \pm 0.01)}} \\
& =10^{4.59 \pm 0.02} \\
& =38900 \pm 2000 \\
& \simeq 40000
\end{aligned}
$$

Fig. 11 Tautomeric equilibrium for 9-methylhypoxanthine between the zwitterionic, ${ }^{+} \mathrm{H} \cdot \mathrm{N} 7(9 \mathrm{MeHx}) \mathrm{N} 1^{-}$, and the neutral, $\mathrm{N} 7(9 \mathrm{MeHx}) \mathrm{N} 1 \cdot \mathrm{H}$, forms, together with the calculation procedure for the ratio $R^{*}$ based on the corresponding micro acidity constants (see also Table 3). 
For adenosine, another tautomeric equilibrium, the one between an amino and an imino form, is expected to be of more relevance in the physiological $\mathrm{pH}$ range since it persists under these conditions and most likely it is also meaningful with regard to mutations occurring in nature. The tautomeric equilibrium for adenosine between its amino and imino form is displayed on the top in Fig. 12. In the context of equilibrium 4a in Section 2.2, we have already seen that 1-methyladenosine may lose a proton from its (C6) $\mathrm{NH}_{2}$ group and that the resulting zwitterionic species stabilizes itself by tautomerizing to the imino form as shown in the middle part of Fig. 12. By use of the corresponding acidity constants, one may calculate [24] the ratio of the two tautomers as shown in the lower part of Fig. 12. It is evident that the amino form of Ado strongly dominates: Among 100000 adenosine molecules, approximately one is present in the imino form, which is enough for initiating mutations.

\section{Ado: tautomeric equilibrium}<smiles></smiles>

amino form<smiles>[Y]C1C=CCC1</smiles><smiles>N=c1[nH]cnc2c1ncn2P</smiles>

imino form<smiles></smiles>

(1MeAdo) ${ }^{+}$<smiles></smiles>

$(1 \text { MeAdo - H })^{0}$

$$
\begin{aligned}
K_{\mathrm{T}}=\frac{K_{\mathrm{a} / 1 \text { MeAdo }}}{K_{\mathrm{a} / \mathrm{H} \text { (Ado) }}} & =\frac{10^{-(8.69 \pm 0.03)}}{10^{-(3.61 \pm 0.03)}} \\
=\frac{[\text { imino }]}{[\text { amino }]} & =10^{-(5.08 \pm 0.04)} \simeq 10^{-5} \\
& =\frac{1}{100000}
\end{aligned}
$$

Fig. 12 Tautomeric equilibrium between the amino and imino forms of adenosine. The calculation shows (for details of the procedure, see [24]) that the amino form at the left is strongly favored. The acidity constants used in the calculation are from Table 1.

\section{EFFECT OF METAL ION COORDINATION ON THE ACID-BASE PROPERTIES OF PURINE NUCLEOBASES}

\subsection{Metal ions and 9-ethylguanine}

In complexation reactions of divalent and labile metal ions $\left(\mathrm{M}^{2+}\right)$ with guanine derivatives in aqueous solution, the protonation equilibria $6 \mathrm{a}$ and $7 \mathrm{a}$ of Section 3 (they are repeated below) as well as the complex-forming equilibria $9 \mathrm{a}$ and $10 \mathrm{a}$ need to be considered [30]. The species $\mathrm{H}(\mathrm{G})^{+}$carries a proton at N7, G represents the neutral guanine derivative, in this section specifically 9-ethylguanine (9EtG) (Fig. 1), and $(\mathrm{G}-\mathrm{H})^{-}$the corresponding species deprotonated at $\mathrm{N} 1$ :

$$
\begin{aligned}
\mathrm{H}(\mathrm{G})^{+} & \rightleftharpoons \mathrm{G}+\mathrm{H}^{+} \\
K_{\mathrm{H}(\mathrm{G})}^{\mathrm{H}} & =[\mathrm{G}]\left[\mathrm{H}^{+}\right] /\left[\mathrm{H}(\mathrm{G})^{+}\right]
\end{aligned}
$$




$$
\begin{aligned}
& \mathrm{G} \rightleftharpoons(\mathrm{G}-\mathrm{H})^{-}+\mathrm{H}^{+} \\
& K_{\mathrm{G}}^{\mathrm{H}}=\left[(\mathrm{G}-\mathrm{H})^{-}\right]\left[\mathrm{H}^{+}\right] /[\mathrm{G}] \\
& \mathrm{M}^{2+}+\mathrm{G} \rightleftharpoons \mathrm{M}(\mathrm{G})^{2+} \\
& K_{\mathrm{M}(\mathrm{G})}^{\mathrm{M}}=\left[\mathrm{M}(\mathrm{G})^{2+}\right] /\left(\left[\mathrm{M}^{2+}\right][\mathrm{G}]\right) \\
& \mathrm{M}^{2+}+(\mathrm{G}-\mathrm{H})^{-} \rightleftharpoons \mathrm{M}(\mathrm{G}-\mathrm{H})^{+} \\
& K_{\mathrm{M}(\mathrm{G}-\mathrm{H})}^{\mathrm{M}}=\left[\mathrm{M}(\mathrm{G}-\mathrm{H})^{+}\right] /\left(\left[\mathrm{M}^{2+}\right]\left[(\mathrm{G}-\mathrm{H})^{-}\right]\right)
\end{aligned}
$$

Of course, the complex $\mathrm{M}(\mathrm{G})^{2+}$ formed according to equilibrium 9a may lose a proton from its (N1)H site to give $\mathrm{M}(\mathrm{G}-\mathrm{H})^{+}$according to equilibrium 11a:

$$
\begin{aligned}
\mathrm{M}(\mathrm{G})^{2+} & \rightleftharpoons \mathrm{M}(\mathrm{G}-\mathrm{H})^{+}+\mathrm{H}^{+} \\
K_{\mathrm{M}(\mathrm{G})}^{\mathrm{H}} & =\left[\mathrm{M}(\mathrm{G}-\mathrm{H})^{+}\right]\left[\mathrm{H}^{+}\right] /\left(\left[\mathrm{M}(\mathrm{G})^{2+}\right]\right.
\end{aligned}
$$

At this point, it is important to note that equilibria 7a, 9a, 10a, and 11a are connected with each other as is evident from the equilibrium scheme 12:

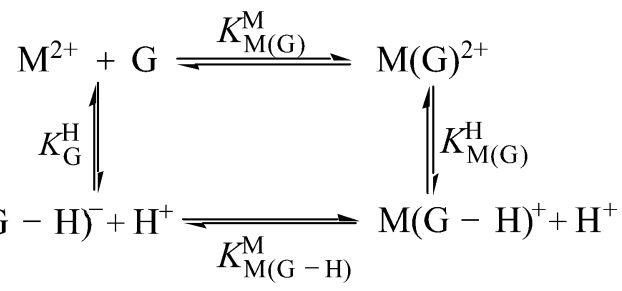

This scheme involves four equilibrium constants and because it is of a cyclic nature only three constants are independent of each other; the size of the fourth constant is automatically determined by the other three as follows from eqs. 13 and 14:

$$
\begin{aligned}
& \log K_{\mathrm{M}(\mathrm{G})}^{\mathrm{M}}-\mathrm{p} K_{\mathrm{M}(\mathrm{G})}^{\mathrm{H}}=\log K_{\mathrm{M}(\mathrm{G}-\mathrm{H})}^{\mathrm{M}}-\mathrm{p} K_{\mathrm{G}}^{\mathrm{H}} \\
& \mathrm{p} K_{\mathrm{M}(\mathrm{G})}^{\mathrm{H}}=\mathrm{p} K_{\mathrm{G}}^{\mathrm{H}}+\log K_{\mathrm{M}(\mathrm{G})}^{\mathrm{M}}-\log K_{\mathrm{M}(\mathrm{G}-\mathrm{H})}^{\mathrm{M}}
\end{aligned}
$$

The acidification of the $(\mathrm{N} 1) \mathrm{H}$ site in $\mathrm{M}(9 \mathrm{EtG})^{2+}$ complexes, as caused by the (N7)-coordinated metal ions, may be defined by eq. 15 :

$$
\Delta \mathrm{p} K_{\mathrm{a}}=\mathrm{p} K_{\mathrm{G}}^{\mathrm{H}}-\mathrm{p} K_{\mathrm{M}(\mathrm{G})}^{\mathrm{H}}
$$

The corresponding results [30] for the $\mathrm{Cu}(9 \mathrm{EtG})^{2+}$ and $\mathrm{Ni}(9 \mathrm{EtG})^{2+}$ complexes are summarized in Table 4 (entries 2, 3).

With Pt(II), a kinetically inert metal ion, the situation is easier since it can be "fixed" at N7; it was used in the form (Dien) $\mathrm{Pt}^{2+}$ because then only a single coordination site is left, which is tied up by N7 of $9 \mathrm{EtG}$ and consequently, $\mathrm{p} K_{(\mathrm{Dien}) \mathrm{Pt}(9 \mathrm{EtG}-N 7)}^{\mathrm{H}}$ (eq. 11) can directly be measured by potentiometric $\mathrm{pH}$ titration [36] (Table 4, entry 4) or by ${ }^{1} \mathrm{H}$ NMR shift experiments [32,37].

For the complexes of inosine with $\mathrm{Pd}^{2+}[38]$ and $\mathrm{Pt}^{2+}$ [39] it has been shown [30] that the acidifying properties of the two metal ions are identical within the error limits. Therefore, based on the mentioned (Table 4) plus additional results, it has been concluded [30] that the acidifying effect of (N7)-coordinated divalent metal ions on the deprotonation of $(\mathrm{N} 1) \mathrm{H}$ sites in guanine derivatives decreases in the series $\mathrm{Cu}^{2+}>\mathrm{Ni}^{2+}>\mathrm{Pt}^{2+} \simeq \mathrm{Pd}^{2+}$, the $\Delta \mathrm{p} K_{\mathrm{a}}$ values being on the order of about $2.2 \pm 0.3>1.7 \pm$ $0.15>1.4 \pm 0.1 \simeq 1.4$, respectively. 
Table 4 Logarithms of the stability constants of $\mathrm{M}(\mathrm{G})^{2+}$ and $\mathrm{M}(\mathrm{G}-\mathrm{H})^{+}$complexes, where $\mathrm{G}=9$-ethylguanine, as well as negative logarithms of related acidity constants as determined by potentiometric $\mathrm{pH}$ titrations (aq. solution; $25^{\circ} \mathrm{C} ; I=0.1 \mathrm{M}, \mathrm{NaNO}_{3}$ ) together with the acidifying effect of $\mathrm{M}^{2+}$ as expressed by $\Delta \mathrm{p} K_{\mathrm{a}}$ (eq. 15$){ }^{\mathrm{a}}$

\begin{tabular}{|c|c|c|c|c|c|}
\hline No. & $\begin{array}{c}\mathrm{H}^{+} \\
\text {or } \\
\mathrm{M}^{2+}\end{array}$ & $\begin{array}{c}\mathrm{p} K_{\mathrm{H}(\mathrm{G})}^{\mathrm{H}} \\
\text { or } \\
\log K_{\mathrm{M}(\mathrm{G})}^{\mathrm{M}} \\
\text { (eqs. 6,9) }\end{array}$ & $\begin{array}{c}\log K_{\mathrm{M}(\mathrm{G}-\mathrm{H})}^{\mathrm{M}} \\
\quad \text { (eq. 10) }\end{array}$ & $\begin{array}{c}\mathrm{p} K_{\mathrm{G}}^{\mathrm{H}} \\
\text { or } \\
\mathrm{p} K_{\mathrm{M}(\mathrm{G})}^{\mathrm{H}} \\
\text { (eqs. } 7,11,14 \text { ) }\end{array}$ & $\begin{array}{c}\Delta \mathrm{p} K_{\mathrm{a}} \\
\text { (eq. } 15)\end{array}$ \\
\hline 1 & $\mathrm{H}^{+}$ & $3.27 \pm 0.03$ & & $9.57 \pm 0.05$ & \\
\hline 2 & $\mathrm{Cu}^{2+}$ & $2.42 \pm 0.09$ & $4.7 \pm 0.4$ & $7.3 \pm 0.4$ & $2.3 \pm 0.4$ \\
\hline 3 & $\mathrm{Ni}^{2+}$ & $1.76 \pm 0.10$ & $3.48 \pm 0.13$ & $7.85 \pm 0.17$ & $1.72 \pm 0.18$ \\
\hline 4 & $\mathrm{Pt}^{2+}$ & & & $8.17 \pm 0.03$ & $1.40 \pm 0.06$ \\
\hline
\end{tabular}

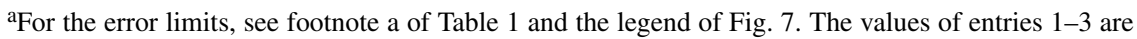
from [30]; entry 4 is from [36] and refers to the (Dien) $\mathrm{Pt}(9 \mathrm{EtG}-N 7)^{2+}$ complex, where Dien $=$ diethylenetriamine $=3$-azapentane-1,5-diamine.

\subsection{The acidifying effects of metal ions at N1 or N7 are reciprocal}

What is the effect of a metal ion coordinated at $\mathrm{N} 7$ on the $(\mathrm{N} 1) \mathrm{H}$ site of a guanine or hypoxanthine residue and what is it if the same metal ion is bound at the (N1) ${ }^{-}$site on the (N7) $\mathrm{H}^{+}$unit? These questions are intriguing and for several years the answers were confusing.

It is evident that a simple way to pursue the above problem is to employ Pt(II) because it binds in a kinetically inert way to N1 and also to N7 of purines and consequently, the acidification on the (N1)H and $(\mathrm{N} 7) \mathrm{H}^{+}$sites can directly be measured [32]. We shall consider here the (Dien) $\mathrm{Pt}^{2+}$ complexes of 9-methylhypoxanthine (9MeHx) [30,32]: In (Dien) $\mathrm{Pt}(9 \mathrm{MeHx}-N 7)^{2+} \mathrm{Pt}(\mathrm{II})$ is coordinated to N7 of neutral 9MeHx, whereas in (Dien) $\mathrm{Pt}\left[{ }^{+} \mathrm{H} \cdot \mathrm{N} 7(9 \mathrm{MeHx}-\mathrm{H}) \mathrm{Nl}^{-}\right]^{2+} \mathrm{Pt}(\mathrm{II})$ is coordinated to the deprotonated $(\mathrm{N} 1)^{-}$site and the proton is relocated to $\mathrm{N} 7$ of the zwitterionic ${ }^{+} \mathrm{H} \cdot \mathrm{N} 7(9 \mathrm{MeHx}) \mathrm{N} 1^{-}$ligand (see also Sections 2.2 and 3 for the nomenclature).

The acid-base properties of $\mathrm{H}(9 \mathrm{MeHx})^{+}$are known [20,30] (Tables 2 and 3) and those of the two $\mathrm{Pt}^{2+}$ complexes were calculated [30] by using published ${ }^{1} \mathrm{H}$ NMR data [40] referring to the chemical shift in dependence on $\mathrm{pH}\left(\mathrm{pH}^{*}\right)$ in aqueous solution $\left(\mathrm{D}_{2} \mathrm{O}\right)$; the resulting values were then transformed [30] to $\mathrm{H}_{2} \mathrm{O}$ as solvent by applying eq. 16 [41] (for details see [30]):

$$
\mathrm{p} K_{\mathrm{a} / \mathrm{H}_{2} \mathrm{O}}=\left(\mathrm{p} K_{\mathrm{a} / \mathrm{D}_{2} \mathrm{O}}-0.45\right) / 1.015
$$

The corresponding results are given in entries 2 and 3 of Table 5. Calculation of the acidification according to eq. 15 for the complex with (N7)-coordinated $\mathrm{Pt}^{2+}$ leads to the result in the final column of entry 2 and is as one would expect; i.e., $\mathrm{Pt}^{2+}$ at $\mathrm{N} 7$ acidifies $(\mathrm{N} 1) \mathrm{H}$ of $9 \mathrm{MeHx}$. However, from entry 3 of Table 5, it follows that coordination of $\mathrm{Pt}^{2+}$ to the $(\mathrm{N} 1)^{-}$site makes $\mathrm{N} 7$ more basic; therefore, the $\Delta \mathrm{p} K_{\mathrm{a}}$ value carries a negative sign. In other words, replacement of $\mathrm{H}^{+}$at $(\mathrm{N} 1)^{-}$by $\mathrm{Pt}^{2+}$ makes the $(\mathrm{N} 7) \mathrm{H}^{+}$site less acidic compared with the situation in $\mathrm{H}(9 \mathrm{MeHx})^{+}$; one could also say, $\mathrm{Pt}^{2+}$ is less polarizing than $\mathrm{H}^{+}$.

However, there is a caveat here which becomes evident if one compares the structures shown in Fig. 13: The two formulas at the top refer to the comparison made between entries 1 and 2 of Table 5 giving $\Delta \mathrm{p} K_{\mathrm{a}}=1.54 \pm 0.08$, whereas the two formulas in the middle refer to the comparison between entries 1 and 3 (Table 5, column 3) giving $\Delta \mathrm{p} K_{\mathrm{a}}=-1.15 \pm 0.25$. Note, the charge difference between the two compounds seen at the top of Fig. 13 is two, whereas between the two compounds in the middle it is only one. Hence, though the result of entry 3 in Table 5 is correct in its own right, it should not be compared with the one given in entry 2 since the two entries do not correspond to each other. 
Table 5 Acidity constant comparisons for 9-methylhypoxanthine systems with (Dien) $\mathrm{Pt}^{2+}$ coordinated either to $\mathrm{N} 7$ or to (N1)- (the data refer to aqueous solutions). ${ }^{\mathrm{a}}$

\begin{tabular}{llccc}
\hline No. & \multicolumn{1}{c}{ Acid } & $\mathrm{p} K_{(\mathrm{N} 7) \mathrm{H}}^{\mathrm{H}}$ & $\mathrm{p} K_{(\mathrm{N} 1) \mathrm{H}}^{\mathrm{H}}$ & \multicolumn{1}{c}{$\Delta \mathrm{p} K_{\mathrm{a}}$} \\
\hline $1^{\mathrm{b}}$ & $\mathrm{H}(9 \mathrm{MeHx})^{+}$ & $1.87 \pm 0.01$ & $9.21 \pm 0.01$ & \\
$2^{\mathrm{c}}$ & $(\mathrm{Dien}) \mathrm{Pt}(9 \mathrm{MeHx}-N 7)^{2+}$ & & $7.67 \pm 0.08$ & $1.54 \pm 0.08$ \\
$3^{\mathrm{c}}$ & $(\mathrm{Dien}) \mathrm{Pt}\left[{ }^{+} \mathrm{H} \cdot \mathrm{N} 7(9 \mathrm{MeHx}-\mathrm{H}) N 1^{-}\right]^{2+}$ & $3.02 \pm 0.25$ & & $-1.15 \pm 0.25$ \\
\hline $4^{\mathrm{d}}$ & ${ }^{+} \mathrm{H} \cdot \mathrm{N} 7(9 \mathrm{MeHx}) \mathrm{N} 1^{-}$ & $4.62 \pm 0.02$ & & $1.60 \pm 0.25$ \\
\hline
\end{tabular}

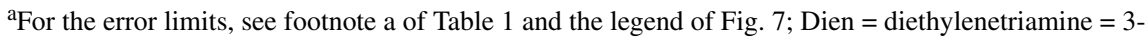
azapentane-1,5-diamine.

${ }^{\mathrm{b}} I=0.1 \mathrm{M}, \mathrm{NaNO}_{3} ; 25^{\circ} \mathrm{C}$. Values from [30].

${ }^{\mathrm{c}} I \simeq 0.01-0.1 \mathrm{M}$; ambient temperature [40]. The constants were calculated [30] based on published ${ }^{1} \mathrm{H}$ NMR shift data [40].

${ }^{\mathrm{d}}$ The micro acidity constant $\left(25^{\circ} \mathrm{C} ; I=0.1 \mathrm{M}, \mathrm{NaNO}_{3}\right)$ given for the release of the proton from $(\mathrm{N} 7) \mathrm{H}^{+}$ under conditions where $\mathrm{N}^{-}$is free is from [20] (see also entry 2 of Table 3, column 5). The $\Delta \mathrm{p} K_{\mathrm{a}}$ value given in the final column is the difference between the $\mathrm{p} K_{(\mathrm{N} 7) \mathrm{H}}^{\mathrm{H}}$ values in column 3 of entries 4 and 3 (see also text in Section 5.2).

In the bottom part and at the left of Fig. 13 the zwitterionic ${ }^{+} \mathrm{H} \cdot \mathrm{N} 7(9 \mathrm{MeHx}) \mathrm{N} 1^{-}$species is shown; its overall charge is zero and hence, the acid-base property of this tautomer of $9 \mathrm{MeHx}$ needs to be compared with that of its $\mathrm{Pt}^{2+}$ complex (Dien) $\mathrm{Pt}\left[{ }^{+} \mathrm{H} \cdot \mathrm{N} 7(9 \mathrm{MeHx}-\mathrm{H}) \mathrm{Nl}^{-}\right]^{2+}$. In other words, one has to use in the comparison the micro acidity constant (entry 4 of Table 5, column 3 ) which describes the deprotonation of the (N7) $\mathrm{H}^{+}$site for a ligand with a deprotonated (N1) ${ }^{-}$unit! This is done in entry 4 of Table 5, where $\Delta \mathrm{p} K_{\mathrm{a}}$ is now correctly calculated as $\mathrm{p} k_{\mathrm{H} \cdot \mathrm{N} 7-\mathrm{N} 1}^{\mathrm{N} 7}-\mathrm{p} K_{\mathrm{Pt} / \text { complex }}^{\mathrm{H}}=(4.62 \pm 0.02)-(3.02 \pm$<smiles>Cc1nc2c(=O)[nH]cnc2n1C</smiles>

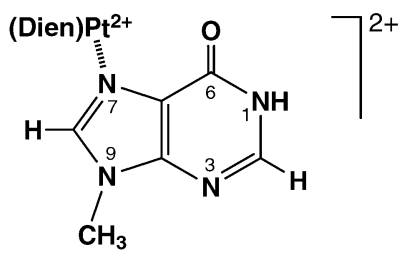<smiles></smiles>

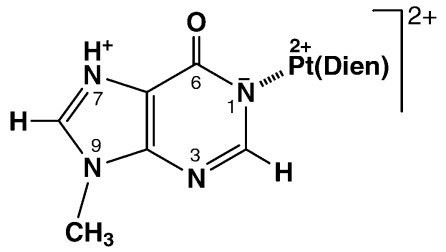

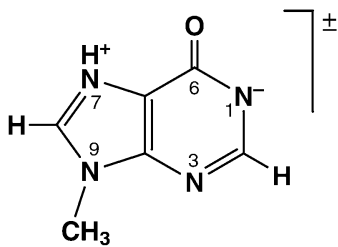

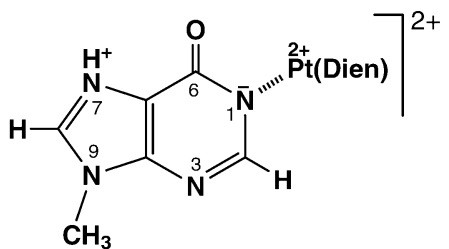

Fig. 13 Structural formulas of several 9-methylhypoxanthine $(9 \mathrm{MeHx})$ species together with those of the (Dien) $\mathrm{Pt}(9 \mathrm{MeHx}-N 7)^{2+}$ (top; right side) and (Dien) $\mathrm{Pt}\left[{ }^{+} \mathrm{H} \cdot \mathrm{N} 7(9 \mathrm{MeHx}-\mathrm{H}) \mathrm{Nl}^{-}\right]^{2+}$ (middle and bottom; right side) complexes (see also text in Section 5.2). 
$0.25)=1.60 \pm 0.25$. Now, based on the correct comparisons, the $\Delta \mathrm{p} K_{\mathrm{a}}$ values of entries 2 and 4 in Table 5 (column 5) are identical within their error limits, proving indeed that the acidifications are reciprocal as one might have expected!

To conclude, it needs to be emphasized that the above result is universal and valid not only for hypoxanthine systems, but also for complexes involving guanine or adenine residues [32]: An acidification of a metal ion at $\mathrm{N} 7$ on the $(\mathrm{N} 1) \mathrm{H}^{0 /+}$ site is always identical with that of a metal ion at $(\mathrm{N} 1)^{-/ 0}$ on the $(\mathrm{N} 7) \mathrm{H}^{+}$site!

\subsection{The proton "outruns" divalent metal ions in acidifications!}

We have already seen in Section 5.1 that the polarizing power and, hence, the extent of acidification differs for different metal ions, and in Section 5.2 we noted that the acidifying properties of $\mathrm{Pt}^{2+}$, if one considers metal ion and proton binding at N1 versus N7, are reciprocal, provided the comparison is based on the coordination of $\mathrm{Pt}^{2+}$ and $\mathrm{H}^{+}$to the two isocharged tautomers of a given purine ligand. However, by the use of micro acidity constants further comparisons become possible [32]. For these, 9EtG was selected here as a representative for guanines and hypoxanthines because the largest set of data is available for this ligand.

From entry 1 in Table 6 , where $\mathrm{H}^{+}$or $\mathrm{M}^{2+}$ binding to $\mathrm{N} 7$ and their effect on the deprotonation of the $(\mathrm{N} 1) \mathrm{H}$ site is considered, one sees again that different metal ions have a different acidifying effect and thus, a different polarizing power $\left(\mathrm{Cu}^{2+}>\mathrm{Ni}^{2+}>\mathrm{Pt}^{2+}\right)$. However, the largest effect is clearly

Table 6 Comparison of the effect of the proton and of several divalent metal ions on deprotonation reactions involving 9 -ethylguanine $(9 \mathrm{EtG} ; \mathrm{N} 7-\mathrm{N} 1 \cdot \mathrm{H})$ in aq. solution. ${ }^{\mathrm{a}}$

\begin{tabular}{|c|c|c|c|c|c|}
\hline \multirow{2}{*}{$\frac{\text { No. }}{1 \mathrm{a}}$} & \multicolumn{3}{|c|}{ Deprotonation reaction } & \multirow{2}{*}{$\frac{\mathrm{p} K_{\mathrm{a}} \text { or } \mathrm{p} k_{\mathrm{a}}}{7.22 \pm 0.01^{\mathrm{c}}}$} & \multirow{2}{*}{$\frac{\Delta \mathrm{p} K_{\mathrm{a}}^{\mathrm{b}}}{2.35 \pm 0.05}$} \\
\hline & ${ }^{+} \mathrm{H} \cdot \mathrm{N} 7-\mathrm{N} 1 \cdot \mathrm{H}$ & $=$ & ${ }^{+} \mathrm{H} \cdot \mathrm{N} 7-\mathrm{N} 1^{-}+\mathrm{H}^{+}$ & & \\
\hline $\mathrm{b}$ & ${ }^{2+} \mathrm{Cu} \cdot \mathrm{N} 7-\mathrm{N} 1 \cdot \mathrm{H}$ & $\Longrightarrow$ & ${ }^{2+} \mathrm{Cu} \cdot \mathrm{N} 7-\mathrm{N} 1^{-}+\mathrm{H}^{+}$ & $7.3 \pm 0.4$ & $2.27 \pm 0.40$ \\
\hline $\mathrm{c}$ & ${ }^{2+} \mathrm{Ni} \cdot \mathrm{N} 7-\mathrm{N} 1 \cdot \mathrm{H}$ & $=$ & ${ }^{2+} \mathrm{Ni} \cdot \mathrm{N} 7-\mathrm{N} 1^{-}+\mathrm{H}^{+}$ & $7.85 \pm 0.17$ & $1.72 \pm 0.18$ \\
\hline $\mathrm{d}$ & ${ }^{2+} \mathrm{Pt} \cdot \mathrm{N} 7-\mathrm{N} 1 \cdot \mathrm{H}$ & $=$ & ${ }^{2+} \mathrm{Pt} \cdot \mathrm{N} 7-\mathrm{N} 1^{-}+\mathrm{H}^{+}$ & $8.35 \pm 0.20^{\mathrm{d}}$ & $1.22 \pm 0.21$ \\
\hline $\mathrm{e}$ & $\mathrm{N} 7-\mathrm{N} 1 \cdot \mathrm{H}$ & $=$ & $\mathrm{N} 7-\mathrm{N} 1^{-}+\mathrm{H}^{+}$ & $9.57 \pm 0.05$ & \\
\hline $2 \mathrm{a}$ & ${ }^{+} \mathrm{H} \cdot \mathrm{N} 7-\mathrm{N} 1 \cdot \mathrm{H}$ & $=$ & $\mathrm{N} 7-\mathrm{N} 1 \cdot \mathrm{H}+\mathrm{H}^{+}+\mathrm{H}^{+}$ & $3.27 \pm 0.03$ & $2.35 \pm 0.07$ \\
\hline$b^{e}$ & ${ }^{+} \mathrm{H} \cdot \mathrm{N} 7-\mathrm{N1}^{-} \cdot \mathrm{Cu}^{2+}$ & $=$ & $\mathrm{N} 7-\mathrm{N}^{-} \cdot \mathrm{Cu}^{2+}+\mathrm{H}^{+}$ & $(3.35 \pm 0.40)$ & $(2.27 \pm 0.40)$ \\
\hline$c^{e}$ & ${ }^{+} \mathrm{H} \cdot \mathrm{N} 7-\mathrm{N1}^{-} \cdot \mathrm{Ni}^{2+}$ & $\Longrightarrow$ & $\mathrm{N} 7-\mathrm{N}^{-} \cdot \mathrm{Ni}^{2+}+\mathrm{H}^{+}$ & $(3.90 \pm 0.19)$ & $(1.72 \pm 0.20)$ \\
\hline $\mathrm{d}$ & ${ }^{+} \mathrm{H} \cdot \mathrm{N} 7-\mathrm{N} 1^{-} \cdot \mathrm{Pt}^{2+}$ & $\Longrightarrow$ & $\mathrm{N} 7-\mathrm{N} 1^{-} \cdot \mathrm{Pt}^{2+}+\mathrm{H}^{+}$ & $4.42 \pm 0.20^{f}$ & $1.20 \pm 0.21$ \\
\hline $\mathrm{e}$ & ${ }^{+} \mathrm{H} \cdot \mathrm{N} 7-\mathrm{N} 1{ }^{-}$ & $=$ & $\mathrm{N} 7-\mathrm{N} 1^{-}+\mathrm{H}^{+}$ & $5.62 \pm 0.06^{\mathrm{c}}$ & \\
\hline
\end{tabular}

${ }^{\text {a}}$ For the error limits, see footnote a of Table 1 and the legend of Fig. $7 . \mathrm{Ni}^{2+}$ or $\mathrm{Cu}^{2+}$ are coordinated to the indicated ligand binding sites; their remaining coordination positions are occupied by $\mathrm{H}_{2} \mathrm{O}$. In the case of $\mathrm{Pt}^{2+}$ (entries $\mathrm{d}$ ) the remaining three positions are occupied by Dien (= diethylenetriamine $=$ 3 -azapentane-1,5-diamine). The above data are abstracted from Table 4 in [32]. The constants refer to $25^{\circ} \mathrm{C}$ and $I=0.1 \mathrm{M}\left(\mathrm{NaNO}_{3}\right)[20,30,32]$, except for the $\mathrm{Pt}^{2+}$ systems (entries d) where $I \simeq 0.01-0.1$ $\mathrm{M}$ and ambient temperature [32,37a].

${ }^{\mathrm{b}}$ The difference is always calculated with the final entry e of a data set.

${ }^{\mathrm{c}}$ Micro acidity constants taken from Fig. S9 of the Supporting Information for [20] (see also [32]).

${ }^{\mathrm{d}}$ The corresponding result given in entry 4 of Table 4 was determined by potentiometric $\mathrm{pH}$ tirations and is certainly more exact. The above value is the result [32] of ${ }^{1} \mathrm{H}$ NMR shift measurements [37a] and was used here for reasons of consistency because entry $2 \mathrm{~d}$ is from the same data set.

'These values are given in parentheses because they have not been measured directly; they were calculated [32] assuming "reciprocity" (see Section 5.2) by using the $\Delta \mathrm{p} K_{\mathrm{a}}$ values of entry 1.

fThe calculated error limit of \pm 0.09 [32] was enlarged to \pm 0.20 because the NMR evaluation (see Fig. S1 of the Supporting Information for [32]) is based on 11 data points, but only 4 of them are in the critical $\mathrm{pD}$ range which mainly determines the $\mathrm{p} K_{\mathrm{a}}$ value. 
achieved by the single charged proton as is also seen from entry 2 and confirmed by systems involving 9-methyladenine [32]. This illustrates the known [42] stronger polarizing power of the proton over almost any divalent metal ion; compare, e.g., the acidity of $\mathrm{H}_{3} \mathrm{O}^{+}$with that of $\mathrm{M}\left(\mathrm{H}_{2} \mathrm{O}\right)_{n}^{2+}$ ions. Overall, these results conform to the principle [32], first formulated by Martin [43], based on results obtained with $\mathrm{Pd}^{2+}$ complexes [38], that a proton-proton interaction is of greater magnitude than a metal ion-proton interaction, which in turn is greater than a metal ion-metal ion interaction [36]. The generality of the last mentioned conclusion still needs to be proven.

\section{CONCLUSIONS}

Micro acidity constants are clearly useful data which allow to quantify the intrinsic acid-base properties of certain sites which cannot directly be measured. They also allow the calculation of the tautomeric ratios, e.g., of monoprotonated purine-nucleobase derivatives, that is, of $\mathrm{N} 7-\mathrm{N} 1 \cdot \mathrm{H}$ versus $\mathrm{H} \cdot \mathrm{N} 7-\mathrm{N} 1$ meaning that in one isomer $\mathrm{H}^{+}$is at the N1 site and in the other at N7 [20]. In fact, several of the nucleobase tautomers occurring in low concentration are expected to be also present in nucleic acids and thus possibly be responsible for mutations.

Application of micro acidity constants also leads to insights into the properties of metal ion complexes [30,32]: For example, provided the intrinsic acid-base properties are considered via micro acidity constants, it becomes evident that $\mathrm{Pt}^{2+}$ coordinated to $\mathrm{N} 7$ in guanine, hypoxanthine, or adenine residues acidifies the (N1) $\mathrm{H}^{0 /+}$ site to the same extent as $(\mathrm{N} 1)^{-/ 0}$-coordinated $\mathrm{Pt}^{2+}$ acidifies the $(\mathrm{N} 7) \mathrm{H}^{+}$unit (cf. Section 5.2). This means that the acidification is reciprocal and the so-called increased basicity of $\mathrm{N} 7$ upon $\mathrm{Pt}^{2+}$ coordination to ( $\left.\mathrm{N} 1\right)^{-/ 0}$ results only if comparisons are made on the basis of the macro acidity constants of the ligands (Table 5). In fact, this observation is a result of the more pronounced proton-proton interaction as compared to the divalent metal ion-proton interaction (Section 5.3) [32].

Of course, a consequence of the mentioned reciprocity is that proton binding at (N1) $)^{-/ 0}$ sites of purines decreases metal ion binding at $\mathrm{N} 7$ to the same extent as proton binding at $\mathrm{N} 7$ decreases metal ion binding at $(\mathrm{N} 1)^{-/ 0}$. All these indicated results are certainly meaningful for the acid-base and metal ion-binding properties of nucleobases in nucleic acids.

\section{ACKNOWLEDGMENTS}

Significant parts of the studies described here have been carried out within the COST D8 and D20 programmes in a most enjoyable and fruitful collaboration with Prof. Dr. Bernhard Lippert from the University of Dortmund. His inputs and the competent technical assistance of Mrs. Rita Baumbusch and Mrs. Astrid Sigel in the preparation of this manuscript are gratefully acknowledged. The research summarized in this article was supported by the Swiss National Science Foundation over many years. This research is also part of the COST D20 programme and received in this context support from the Swiss Federal Office for Education and Science.

\section{REFERENCES}

1. R. B. Martin. Acc. Chem. Res. 18, 32-38 (1985).

2. J. D. Watson. The Double Helix, Chap. 26, Atheneum, New York (1968).

3. H. Sigel and B. Lippert. Pure Appl. Chem. 70, 845-854 (1998).

4. W. Saenger. Principles of Nucleic Acid Structure, pp. 1-556, Springer, New York (1984).

5. H. Sigel and B. Song. Met. Ions Biol. Syst. 32, 135-205 (1996).

6. H. Sigel, E. M. Bianchi, N. A. Corfù, Y. Kinjo, R. Tribolet, R. B. Martin. Chem. Eur. J. 7, 3729-3737 (2001).

7. H. Sigel. Pure Appl. Chem. 76, 375-388 (2004). 
8. K. Aoki. Met. Ions Biol. Syst. 32, 91-134 (1996).

9. (a) Y. Kinjo, R. Tribolet, N. A. Corfù, H. Sigel. Inorg. Chem. 28, 1480-1489 (1989); (b) Y. Kinjo, L.-n. Ji, N. A. Corfù, H. Sigel. Inorg. Chem. 31, 5588-5596 (1992).

10. B. Knobloch, C. P. Da Costa, W. Linert, H. Sigel. Inorg. Chem. Commun. 6, 90-93 (2003).

11. H. Sigel. Chem. Soc. Rev. 22, 255-267 (1993).

12. C. F. Moreno-Luque, E. Freisinger, B. Costisella, R. Griesser, J. Ochocki, B. Lippert, H. Sigel. J. Chem. Soc., Perkin Trans. 2, 2005-2011 (2001).

13. B. Knobloch and H. Sigel. J. Biol. Inorg. Chem. 9, 365-373 (2004).

14. H. Sigel. In Nucleoside Triphosphates and Their Analogs: Chemistry, Biotechnology and Biological Applications, M. M. Vaghefi (Ed.), Dekker, New York (2005). In press.

15. R. B. Martin and Y. H. Mariam. Met. Ions Biol. Syst. 8, 57-124 (1979).

16. R. L. Benoit and M. Fréchette. Can. J. Chem. 62, 995-1000 (1984).

17. R. B. Martin. Met. Ions Biol. Syst. 9, 1-39 (1979).

18. B. Song, R. K. O. Sigel, H. Sigel. Chem. Eur. J. 3, 29-33 (1997).

19. R. L. Benoit and M. Fréchette. Can. J. Chem. 63, 3053-3056 (1985).

20. G. Kampf, L. E. Kapinos, R. Griesser, B. Lippert, H. Sigel. J. Chem. Soc., Perkin Trans. 2, 1320-1327 (2002).

21. L. P. Hammett and A. J. Deyrup. J. Am. Chem. Soc. 54, 2721-2739 (1932).

22. M. A. Paul and F. A. Long. Chem. Rev. 57, 1-45 (1957).

23. H. Sigel, A. D. Zuberbühler, O. Yamauchi. Anal. Chim. Acta 255, 63-72 (1991).

24. B. Lippert, H. Schöllhorn, U. Thewalt. Inorg. Chim. Acta 198-200, 723-732 (1992).

25. S.-H. Kim and R. B. Martin. Inorg. Chim. Acta 91, 19-24 (1984).

26. C. Meiser, B. Song, E. Freisinger, M. Peilert, H. Sigel, B. Lippert. Chem. Eur. J. 3, 388-398 (1997).

27. J. E. Šponer, J. Leszczynski, F. Glahé, B. Lippert, J. Šponer. Inorg. Chem. 40, 3269-3278 (2001).

28. J. Elguero, C. Marzin, A. R. Katritzky, P. Linda. The Tautomerism of Heterocycles, Advances in Heterocyclic Chemistry, Suppl. 1, p. 20, Academic Press, New York (1976).

29. H. Sigel, S. S. Massoud, N. A. Corfù. J. Am. Chem. Soc. 116, 2928-2971 (1994).

30. B. Song, J. Zhao, R. Griesser, C. Meiser, H. Sigel, B. Lippert. Chem. Eur. J. 5, 2374-2387 (1999).

31. N. A. Corfù and H. Sigel. Eur. J. Biochem. 199, 659-669 (1991).

32. R. Griesser, G. Kampf, L. E. Kapinos, S. Komeda, B. Lippert, J. Reedijk, H. Sigel. Inorg. Chem. 42, 32-41 (2003).

33. H. Sigel, S. S. Massoud, R. Tribolet. J. Am. Chem. Soc. 110, 6857-6865 (1988).

34. E. M. Bianchi, S. A. A. Sajadi, B. Song, H. Sigel. Chem. Eur. J. 9, 881-892 (2003).

35. R. B. Gómez-Coca, L. E. Kapinos, A. Holý, R. A. Vilaplana, F. González-Vílchez, H. Sigel. J. Chem. Soc., Dalton Trans. 2077-2084 (2000).

36. B. Knobloch, R. K. O. Sigel, B. Lippert, H. Sigel. Angew. Chem., Int. Ed. 43, 3793-3795 (2004).

37. (a) J. L. van der Veer, H. van den Elst, J. Reedijk. Inorg. Chem. 26, 1536-1540 (1987); (b) R. K. O. Sigel, E. Freisinger, B. Lippert. J. Biol. Inorg. Chem. 5, 287-299 (2000).

38. K. M. Scheller, V. Scheller-Krattiger, R. B. Martin. J. Am. Chem. Soc. 103, 6833-6839 (1981).

39. J. Arpalahti and P. Lehikoinen. Inorg. Chem. 29, 2564-2567 (1990).

40. J. H. J. den Hartog, M. L. Salm, J. Reedijk. Inorg. Chem. 23, 2001-2005 (1984).

41. R. B. Martin. Science 139, 1198-1203 (1963).

42. (a) R. B. Martin. J. Am. Chem. Soc. 89, 2501-2502 (1967); (b) B. Noszál, V. Scheller-Krattiger, R. B. Martin. J. Am. Chem. Soc. 104, 1078-1081 (1982).

43. R. B. Martin. Met. Ions Biol. Syst. 32, 61-89 (1996); see p. 84. 